\title{
HUMAN GENETICS: PAST, PRESENT, AND FUTURE, WITH SPECIAL REFERENCE TO MAJOR TRENDS IN JAPAN
}

\author{
Toshiyuki YANASE* \\ Faculty of Medicine, Kyushu University, 3-1-1 Maidashi, \\ Higashi-ku, Fukuoka 812, Japan
}

Key Words historical trends of human genetics, DNA technology, new classes of pathogenic mutation, human cancer genetics, ecogenetics (xenogenetics)

The Japan Society of Human Genetics was established in June 1956 [1]. The year 1996 is thus the 40th anniversary of the founding of this Society.

The present article is concerned with recollections, current perspectives, and prospective views of human genetics in the past, present, and future, with special reference to major trends in Japan.

\section{Human genetics in the early period}

While Mendelism was imported into the Japanese biological societies early in this century and thus led to numerous genetic studies using experimental organisms, relatively few studies had been conducted on human genetics until around $1950[2,3]$.

The eugenic movements had gradually developed from 1930 when the Association of Nation's Hygiene was first organized by a group of medical authorities headed by Hisomu Nagai, the University of Tokyo, who voiced grave concern about the possible "genetic deterioration" of the Japanese nation [3]. Matsunaga (1992) outlined in his article the developmental process of eugenic idea, the National Eugenic Law in the years 1940-1945, and the Eugenic Protection Law in 1948 [3]. Such eugenic movements have since continued to promote the development of human genetics in Japan.

Pioneers of human genetics in Japan. There were pioneers of human

\footnotetext{
A special lecture commemorating the 40th anniversary of the Japan Society of Human Genetics made in Sapporo City on October 24th, 1996.

*Address of the author: Health Care Sawara 219, 24-24, 4-chome Atago, Nishi-ku, Fukuoka 819 , Japan.
} 
Table 1. Three pioneering studies on human genetics before World War II.

\begin{tabular}{lccc}
\hline Name of investigators & Year & Title of studies & Reference \\
\hline Furuhata et al. & 1925 & $\begin{array}{c}\text { Proposal of three multiple allele theory for ABO } \\
\text { blood groups based upon family studies }\end{array}$ & {$[4]$} \\
Imai \& Moriwaki & 1936 & $\begin{array}{c}\text { Proposal of cytoplasmic inheritance for Leber's } \\
\text { optic nerve atrophy }\end{array}$ & {$[6]$} \\
Komai \& Fukuoka & 1936 & \begin{tabular}{c} 
An epidemiological study of twin births \\
\hline
\end{tabular}
\end{tabular}

genetics who published original papers, educational articles, and textbooks relevant to human genetics, while also training a number of junior human geneticists from 1935 to 1955 (Appendix 1). Among the original studies done by these pioneers, three became widely known at the international level (Table 1).

The situations in the first decade following World War II. In the years from 1945 to 1950, when most students started studies of human heredity, genetic studies on experimental organisms were most popular. At that time man was not a favorable subject for studies of this nature for a variety of reasons.

Until around 1955 the students of human genetics, for the most part, focused their attention on the collection of pedigrees in which a given obvious trait appeared, and hence the field of human genetics was regarded as an "uncultivated barren wasteland" in both fields of general genetics and medical biology because of the limitations of its own methodology, and was also often confused with genealogy. Under such circumstances, students of human genetics have thus made great efforts to overcome various obstacles in methodology.

Introductory books to human genetics in the early period. The following textbooks may be listed as those which were invaluable aids for students of human genetics especially in the years from 1950 to 1965 .

C. Stern (1949) The Principles of Human Genetics [7]

J.F. Crow (1950) Genetics Notes [8]

J.V. Neel and W.J. Schull (1954) Human Heredity [9]

K. Tanaka (1960) Fundamental Human Genetics [10]

All of these books, except for "Genetics Notes," have since fallen into disuse and have been gradually replaced by more up-to-date versions, but they nevertheless had a great impact on those students. In 1967 a book commemorating "The Mendel Centennial Anniversary in Japan" was published [11].

Establishment of the Japan Society of Human Genetics. In the early 1950s, an increasing number of younger medical investigators became interested in human heredity, but were frustrated because of the lack of mechanisms for communicating with each other. Some of them joined the annual meetings of the Japan Society of General Genetics, but most of them were disappointed since the methodologies employed in experimental genetics were not appropriate for solving their own problems. Studies of human heredity, which preclude the possibility of using crossing experiments, require totally different approaches $[2,3]$. 
In 1955 , the need for creating an independent society of human genetics was voiced by a group of younger investigators. This group appealed to a number of colleagues to help establishing the society. Finally, as a result of their efforts, the new society was established $[1,2]$.

The first meeting of the Society was held at the Keio University Medical School on June 2nd, 1956, and Tanemoto Furuhata was elected to the first president of the Society $[1,2]$.

International exchanges of knowledge on human genetics at the initial stage. The establishment of the Japan Society of Human Genetics was timely because the First International Conference of Human Genetics was scheduled to take place in Copenhagen in August 1956, while in September 1956 the International Symposium of Genetics was also scheduled to be held in Tokyo and Kyoto, whose programs include a one-day symposium on twin research and human population genetics [3].

Some senior human geneticists including C. Stern, W.C. Boyd, O.v. Verschuer, H. Nachtsheim, R. Turpin, and E. Essenmöller visited Japan to join the symposium. For the majority of human geneticists on the Japanese side it was the first opportunity to have direct discussions with guest speakers. Following the symposia Stern and Verschuer delivered lectures at different universities [3].

The development of human genetics in Japan also owes a lot to J.V. Neel and W.J. Schull of the University of Michigan who have been working in collaboration with Japanese investigators for more than 40 years to study the genetic effects of the atomic bomb in Hiroshima and Nagasaki [12]. They greatly contributed to the development of a number of human geneticists in Japan by demonstrating a leadership in the study of consanguinity in the 1960s and 1970s which will be described later.

In 1956 the first research institute of human genetics was established at the Tokyo Medical and Dental University, and Katumi Tanaka was selected as professor and chairman. This event thereafter led to the establishment of numerous institutions related to human genetics.

Appendix 2 gives a list of the studies and recipients of the Japan Society of Human Genetics Award from 1960 to 1996.

\section{Human genetics at the dawn of a new age}

In 1955 several breakthroughs were seen in some areas of human genetics, which had been stagnant for a long time, particularly in the fields involving statistical, cytological, and biochemical approaches.

\section{A. Genetics in family and population units}

Stochastic and statistical approaches to human heredity had been developed earlier. This stems from a number of sources, but primarily from the fact that human populations are essentially nonexperimental populations and thus not to subject to manipulation by the investigator.

Vol. 42, No. 2, 1997 
In the 1930s Fisher, Haldane, and Wright developed an elaborate theoretical framework of population genetics, in which they consistently studied various problems in human heredity as well as theoretical aspects of population genetics [13-21].

In the 1940 s and 1950 s, the field of human genetics involving statistical approaches to family and population data was subdivided into three specified areas: human population genetics, epidemiological genetics, and statistical genetics [9]. Among the studies which have been done by the successors of Fisher, Haldane, and Wright, the lod score method in the linkage test designed by Morton in 1955 is widely used in gene mapping even at the present time [22].

\section{B. Cytological approaches}

The number and morphology of human chromosomes could not be identified for 60 years after the first study by Flemming in 1897 [23].

Identification of the number and morphology of human chromosomes. Adapting several advanced techniques to cultured fibroblasts of human embryonic lung tissue specimens, Tjio and Levan found in 1956 that earlier teports had erred in reporting the number of human chromosomes; they found 46 rather than 47 or 48 , with the karyotype of females being $46, X X$ and that of males $46, X Y$ [24].

The first discovery of chromosomal aberration. The development of the method to determine the human karyotype enhanced discoveries of a variety of aberrations in the number and morphology of human chromosomes.

The first example of trisomic chromosomes in man was discovered in 1959 by Lejeune and his colleagues [25]. Their paper is still recognized as one of the classics in human genetics, in that it opened the area of human cytogenetics to intensive investigation. Matsunaga (1993) pointed out the following situation with respect to the rapid spread of chromosome studies: Investigators can obtain direct evidence for mutation through observations of aberrant chromosomes using light microscopy. Such findings soon led to a rapid spread of chromosome studies [26].

Further technical developments. Two other technical developments revolutionized the study of human chromosomes. The first was a report of Caspersson and his associates in 1970 that certain fluorescent derivatives of quinacrine bind differently to different parts of chromosomes [27]. Not long after the fluorescent technique became available, studies in several other laboratories led to the development of alternate techniques for detecting the same banding patterns [28]. [29].

The second technical development was the high resolution banding technique

Population cytogenetics. The survey of the incidence of chromosomal aberrations in man was initiated in 1967 by Carr [30]. From 1970 to 1995, a number of attempts were made to estimate the loss of zygotes at the early developmental stages, particularly involving the embryonic, perinatal, and neonatal periods. These data thus led to the approximation of the genetic load due to chromosomal aberrations [31]. 


\section{Biochemical approaches}

It has been recognized for many years that a large number of metabolic disorders can be attributed to the congenital deficiency of a specific enzyme, which in turn is due to the presence of a particular abnormal gene. Such conditions were first called "inborn errors of metabolism" in 1902 by Garrod [32].

This was the beginning of biochemical genetics and the idea that genes control the synthesis of enzymes, which in turn are responsible for carrying out specific biochemical process. In 1941 Beadle and Tatum provided experimental evidence for these ideas based on breeding experiments with bread mould Neurospora crassa [33].

Inborn errors of metabolism in which the defective enzymes had been previously identified. Phenylketonuria discovered by Fölling in 1934 has been studied extensively [34], and in this inborn error deficiency of phenylalanine 4-hydroxylase was identified in 1953 by Jervis [35]. In 1948 Gibson identified a specific deficiency of the red cell enzyme NADH diaphorase in an autosomal recessive case of hereditary methemoglobinemia, while Takahara and Miyamoto identified a gross deficiency of catalase in acatalasemia in 1949 [36, 37]. Cori and Cori demonstrated in 1952 that a deficiency of glucose-6-phosphatase causes a characteristic form of glycogen storage disease known as von Gierke disease [38].

The first identification of point mutation at the protein level. In 1949 Pauling et al. proposed the concept of "molecular disease" based upon a significant difference in mobility in the Tiselius zone electrophoresis between hemoglobins from normal individuals, sickle cell anemia (homozygote), and sickle cell traits (heterozygote) [39]. Using the fingerprinting method of the protein analysis, Ingram showed in 1956 that sickle cell hemoglobin differed from normal hemoglobin in only one amino acid [40]. At a later stage, single amino acid substitution was attributed to single base substitution, which was then the first point mutation identified throughout all organisms.

In the early 1960s population genetics, cytogenetics, and biochemical genetics thus came to be regarded as the three major areas of investigation in human genetics.

\section{Biological effects of inbreeding and genetic load}

During the past century, in most areas of the world isolates have tended to break up, particularly since World War II. The break-up of isolates results in a change in the level and distribution of consanguineous matings. Sutter and Tabah (1954) were among the first to draw attention to the importance of this process, which they attempted to measure by changes in the demographic variables, e.g. endogamy, and consanguineous unions [41]. Nei and Imaizumi (1963) pointed out that the decrease in consanguinity can be partly attributed to a decrease in the mean number of children born and its variance [42]. This theory was proven by a study in a rural community $[43,44]$. 
Consanguinity studies in Japan. The tendency toward endogamy and inbreeding have declined year by year in Japan as well, but it still remains relatively high by world-wide standards [45]. It was therefore a matter of urgency that studies of consanguinity be pursued while there is still time.

For a number of other reasons, Japan was a country suitable for studies on the effects of inbreeding. Particularly, the family registration system, or "Koseki," has provided investigators with a set of open records of highly accurate family relationships, and thus are much less subject to errors of recollection than a usual family history [46].

A series of the Japan-US cooperative studies on consanguinity were conducted from 1957 to 1973, under the support of the Genetic Committee of the Science Council of Japan and the University of Michigan [47-49]. The following five urban populations were thus subjected to the studies:

Shizuoka (T. Komai), Hiroshima (W.J. Schull and J.V. Neel),

Nagasaki (W.J. Schull and J.V. Neel), Fukuoka (T. Yanase),

and Hirado (W.J. Schull and J.V. Neel)

The bracketed names show the principal investigators who were responsible for each study [49-54].

In parallel to these studies, more than 30 rural coastal or inland isolated populations located in northern, central, and southern parts of Japan were also investigated $[43,49]$.

Mortality among the offspring of consanguineous matings. The effects of inbreeding on pre- and postnatal mortalities were studied with the purpose of estimating the amount of hidden genetic load expressed as lethal equivalents per

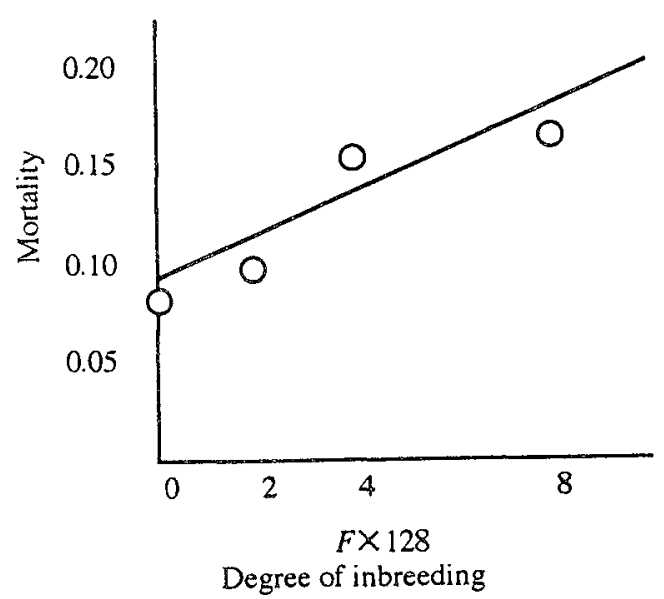

Fig. 1. Regression of early mortality on the degree of inbreeding in an inland rural community.

Yanase 1992 [44]. 
gamete and zygote. As a result, postnatal mortalities among consanguineous groups were generally higher than those among non-consanguineous groups in all five urban populations. Figure 1 gives the nearly schematic data obtained in a rural community, where a linear regression of the death rates up to six years after birth on the degree of inbreeding (coefficient of in breeding $F \times 128=0,2,4$, and $8)$ is shown [44].

Genetic load. The concept of genetic load was first set out by Muller in his special lecture on "our load of mutation" at the annual meeting of the American Society of Human Genetics in 1949 [55], and the theoretical basis of genetic load was thereafter developed largely by Morton, Crow, and Kimura [56-61].

Morton et al. (1956) distinguished between the total damage due to disadvantageous mutations present in the human genome and the expressed damage. These were described as lethal equivalents. A lethal equivalent is a group of mutations that, distributed among various individuals, causes one death, on the average, for genetic reasons $[14,56,57]$.

In a randomly mating population $(F=0)$, the expressed genetic damagetogether with the environmental damage-is represented by $A$. On the other hand, $B$ is a measure for the hidden genetic damage that could manifest itself only with complete homozygosity $(F=1)$. The total genetic damage is the sum of $B$ and the genetic component $A$, and hence, lies between $B$ and $(B+A)$. The linear regression of mortality $(m)$ on degree of inbreeding $(F)$ is thus obtained using by the following formula (Morton-Crow-Muller's model):

$$
m=1-e^{-(A+B F)} \fallingdotseq A+B F
$$

The values of $A$ and $B$ are approximated by the method of maximum likelihood based upon the data on the mortality among the offsprings of consanguineous and non-consanguineous matings $(F=0,1 / 64,1 / 32$, and 1/16).

The concept of genetic load has been extensively discussed by population geneticists [62-64]. On the other hand, it has also been asserted that of the outcome of consanguineous matings as compared with non-consanguineous matings could contribute to the problem of whether detrimental mutations (mutational load) or balanced polymorphisms due to a heterozygote advantage (segregational load) contribute more to the genetic load of human species [62-64]. Table 2 gives the $B / A$ ratios obtained in the studies of five populations. These lower $B / A$ ratios may be explained by segregation involving a preponderance of

Table 2. $B / A$ ratios in five populations.

\begin{tabular}{lcccccc}
\hline Population & $A$ & $B$ & $B / A$ & Ascertainment & Investigator \\
\hline Shizuoka & 0.0647 & 0.5993 & 9.3 & Followed to 6 years & Tanaka 1973 \\
Fukuoka & 0.0682 & 0.6232 & 9.1 & Followed to 6 years & Yamaguchi et al. 1970 \\
Hiroshima & 0.0875 & 0.5317 & 6.1 & Followed to 8 years & Schull \& Neel 1965 \\
Nagasaki & 0.0986 & 0.0106 & 1.1 & Followed to 8 years & Schull \& Neel 1965 \\
Hirado & 0.1157 & 0.7703 & 6.7 & Largely through age 20 & Schull \& Neel 1972 \\
\hline References: $[50-54]$. & & & &
\end{tabular}

Vol. 42, No. 2, 1997 
Table 3. Regression of anthropometric measurements on coefficient of inbreeding $(F)$.

\begin{tabular}{|c|c|c|c|c|c|c|}
\hline \multirow{2}{*}{$\begin{array}{c}\text { Population } \\
\text { Range of months of age } \\
\text { Sex }\end{array}$} & \multicolumn{2}{|c|}{$\begin{array}{c}\text { Shizuoka } \\
76-147 \\
\end{array}$} & \multicolumn{2}{|c|}{$\begin{array}{c}\text { Hiroshima** } \\
60-132 \\
\end{array}$} & \multicolumn{2}{|c|}{$\begin{array}{c}\text { Nagasaki** } \\
66-138\end{array}$} \\
\hline & $\begin{array}{c}\text { Male } \\
\text { children }\end{array}$ & $\begin{array}{c}\text { Female } \\
\text { children }\end{array}$ & $\begin{array}{c}\text { Male } \\
\text { children }\end{array}$ & $\begin{array}{r}\text { Female } \\
\text { children }\end{array}$ & $\begin{array}{c}\text { Male } \\
\text { children }\end{array}$ & $\begin{array}{c}\text { Female } \\
\text { children }\end{array}$ \\
\hline Stature (mm) & -0.4114 & -1.7011 & -0.7078 & -0.5738 & -0.8780 & -0.7051 \\
\hline Sitting height $(\mathrm{mm})$ & -0.1304 & -1.1279 & -0.4647 & -0.4154 & -0.7288 & -0.3167 \\
\hline Chest circumference (mm) & -0.2202 & -0.1270 & -0.2744 & -0.0296 & -0.5290 & -0.3237 \\
\hline Weight $(100 \mathrm{~g})$ & -0.1222 & -0.3040 & -0.3743 & -0.1063 & -0.4876 & -0.3971 \\
\hline Head length (mm) & -0.1047 & -0.1453 & -0.1945 & -0.0954 & -0.0510 & -0.1943 \\
\hline Head breadth $(\mathrm{mm})$ & -0.0841 & -0.0609 & -0.1440 & -0.1838 & -0.0652 & -0.0175 \\
\hline Head circumference ( $\mathrm{mm}$ ) & -0.0054 & -0.1750 & -0.4648 & -0.3009 & -0.1763 & -0.2057 \\
\hline
\end{tabular}

balanced genetic systems of various types, i.e., a segregational load.

Physical development of the offspring of consanguineous matings. Table 3 gives the results of a regression analysis of seven anthropometric measurements of school children on the degree of inbreeding $(F)$ in three populations $[49,51]$. All variables showed some effect of inbreeding suggesting inbreeding depression upon the physical development.

Human isolates. Human isolated populations may be classified into the following four categories [44]:

(1) Offshoot populations in areas geographically distant from the main population [43].

(2) Communities isolated on account of a particular factor, for example, some 2,300 inhabitants on an island in Nagasaki Prefecture clearly constituted two subgroups: one Buddhist and the other Roman Catholic. Very few marriages were contracted between persons from these two religious groups over the past hundred years [65].

(3) Unique Japanese ethnic communities, such as the Ainu who inhabit the northern most part of Japan [44].

(4) Primitive populations of hunter-gatherers still living under conditions comparable with those during prehistoric times [66].

Isolation obviously affects the breeding structure, migration patterns, founder effect, and particularly genetic distance, its theory and actual applications, in other words factors affecting the evolutionary dynamics of a population. However the biological effects of isolation and its break-up, for example on the differentiation of population subgroups, morbidity, mortality, fertility, etc., should also be considered $[44,67]$.

4. The development of gene manipulation and the introduction of recombinant DNA technology into medicine

In about 1960 some indications of a second new current in human genetics 
were seen after the identification of number and morphology of human chromosomes in 1956. Three discoveries may be pointed out as representative events: the discovery of human leukocyte antigens (HLA) by Dausset in 1958, Philadelphia chromosome by Nowell and Hungerford in 1960, and somatic cell hybridization by Okada in 1962 [68-70]. These works apparently formed the basis of human immunogenetics, cancer genetics, and somatic cell genetics which have since developed with the spread of recombinant DNA technology.

The developmental process of gene manipulation. The first steps toward gene manipulation are thought to have been taken in 1944 when Avery and his associates first demonstrated that genetic information is stored in nucleic acid and not protein as previously believed [71]. In 1952 Hershey and Chase proved that genetic information is transferred by DNA alone [72]. Milestones in DNA technology are listed in Table 4. Emery (1984) stated his impressions in the developmental process of DNA technology as follows [73]:

"After the discovery of the double-helical structure of DNA in 1953, interest

Table 4. Milestones in DNA technology.

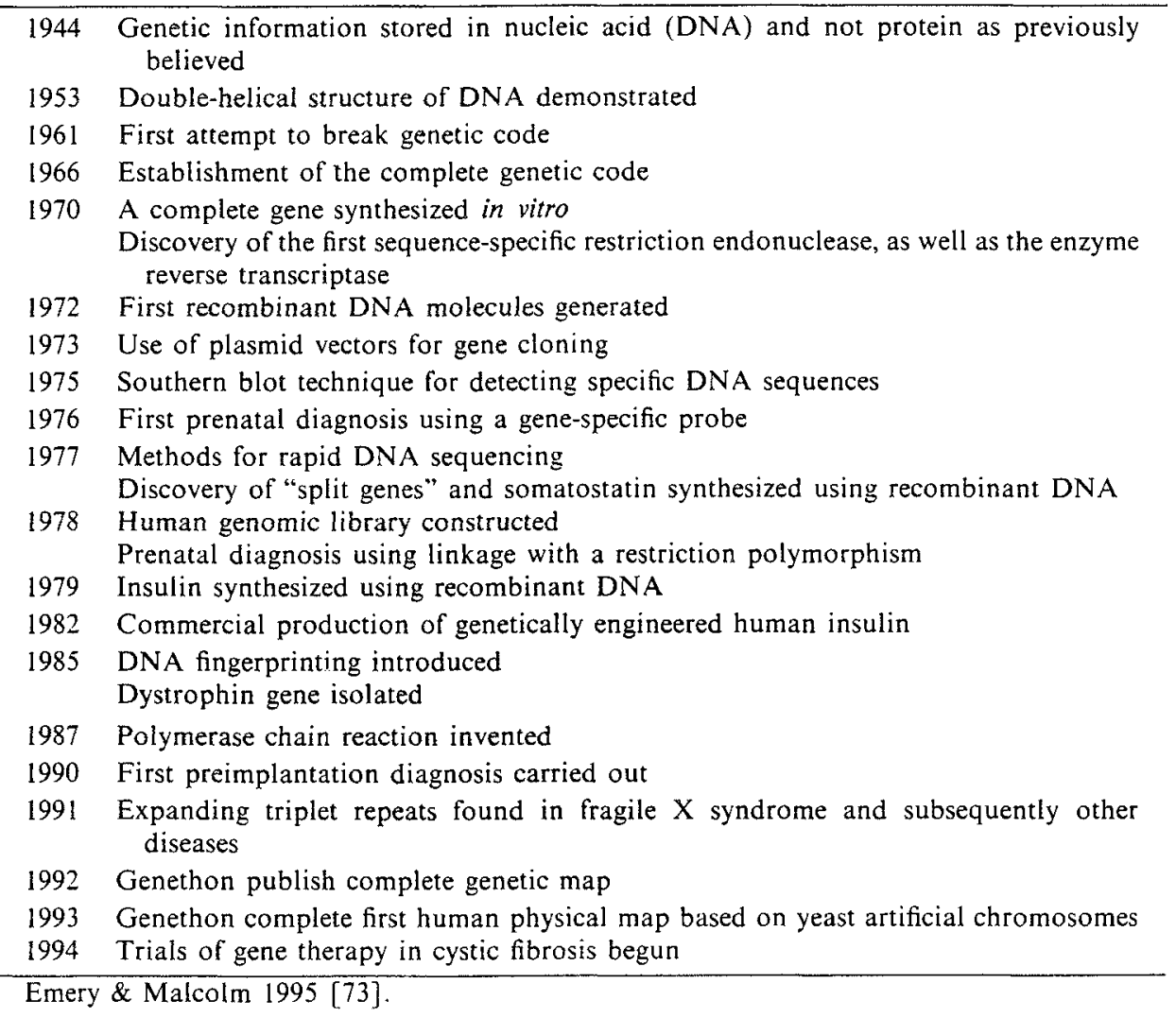

Vol. 42, No. 2, 1997 
in moleculer biology grew considerably. The late 1950s and early 1960s were exciting times for geneticists. Unfortunately it gradually became clear that much of what had been learned in molecular biology did not seem to bear much relevance to man, and to medicine in particular. However, interest was dramatically rekindled in the early 1970s with the advent of recombinant DNA technology or, more popularly, genetic engineering. It soon became clear that through the new technology there could be important applications in the prevention and perhaps treatment of genetic disease."

This statement appears to well describe the impressions of most of human geneticists who passed through the era of DNA technology.

Molecular cytogenetics. Identification of chromosomal aberrations using banded karyotypes has been available for some time, but it is often difficult and requires highly trained technicians to identify the exact origin of a derivative chromosome of particularly poor quality preparations [74]. The prevailing situation greatly changed after the introduction of chromosome "paints" for use in fluorescent in situ hybridization and microdissection painting.

Langer-Safer et al. worked out immunological method for mapping genes on Drosophila polytene chromosomes in 1982, and Pinkel et al. $(1986,1988)$ first applied this technique to the analysis of human chromosomes [75-77]. Subsequently, the microdissection of banded human chromosomes was introduced by Ludeck et al. (1989) and Senger et al. (1990) [78, 79]. Figure 2 shows regional localization of DNA sequences on the corresponding chromosomes which were determined by fluorescent in situ hybridization.

The introduction of such new technologies into chromosome studies has thus promoted the development of a new area called "moleculer cytogenetics." This area may cover broad research projects particularly involving the phenomenon of dosage compensation pertinent to $\mathrm{X}$ chromosome which was first noted by Lyon in 1961, fragile sites of chromosomes, contiguous gene syndrome, and genomic

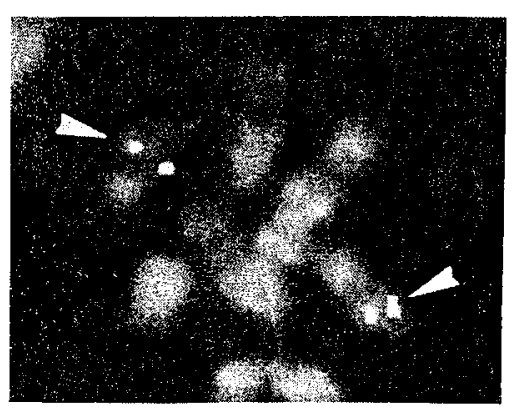

Fig. 2. Fluorescent in situ hybridization of probe DNA to chromosome 18 long arm. H. Nakashima with permission (First Department of Medicine, Kyushu University). 
imprinting [80-90].

Introduction of DNA technology into medicine. The technology of gene manipulation have introduced many innovations especially into medicine (Table 5). Biogenic peptides and proteins, including more than 40 kinds of cytokine and hormone produced by recombinant DNA technology, have become an invaluable aid in both basic and practical medicine [91-96].

The laboratory examinations undertaken so far were only supplementary means to learn the pathophysiology of diseases, but in the near future these will be potentially valuable tools in the etiological analysis of diseases. The first meeting of "gene diagnosis and therapy" in Japan was held in Kyoto in 1994 [92].

Table 6 gives microbes which can be identified more precisely and rapidly using the combined technology of recombinant DNA and somatic cell genetics. Figure 3 shows a case of Pneumocystis carinii pneumonia in which the pathogen was precisely identified by DNA technology.

Table 5. Introduction of gene manipulation and somatic cell genetics into medicine.

1. Production of biogenic peptides and proteins; cytokines, hormones etc.

2. Production of immunological substances against infections; vaccines, monoclonal antibodies, etc.

3. Etiological analysis, diagnosis, prophylaxis, and treatment of unifactorial and multifactorial diseases

(a) Genetical approaches to the pathogenesis of diseases

(b) Medical diagnosis and gene diagnosis

Prenatal and postnatal diagnosis, carrier recognition, etc.

(c) Treatment of diseases

Treatment using biogenic peptides and proteins, gene therapy, etc.

4. New laboratory examinations including the gene diagnosis of microbes

5. Phylogenetic classification of microbes

6. Search for DNA polymorphism in the chromosomal and mitochondrial genomes

7. Introduction of recombinant DNA technology into the legal medicine

Table 6. Microbes which can be identified by DNA technology.

Pneumococcal isolates, group A streptococcal isolates, MRSA

Toxic Clostridium difficile

Mycobacterial isolates, Mycobacterium tuberculosis, pathogenic Escherichia coli, Pseudomonas aeruginosa, Sallmonella strains, Legionella pneumophilia

Borrelia burgdorferi, Treponema pallidum

Rickettsia rickettsi

Chlamydia species

Candida species

Human papilloma virus, hepatitis $\mathrm{C}$ virus, human immunodeficiency virus, cytomegalovirus, herpes simplex virus

Pneumocystis carinii

Miyaji 1996 [93].

Vol. 42, No. 2, 1997 


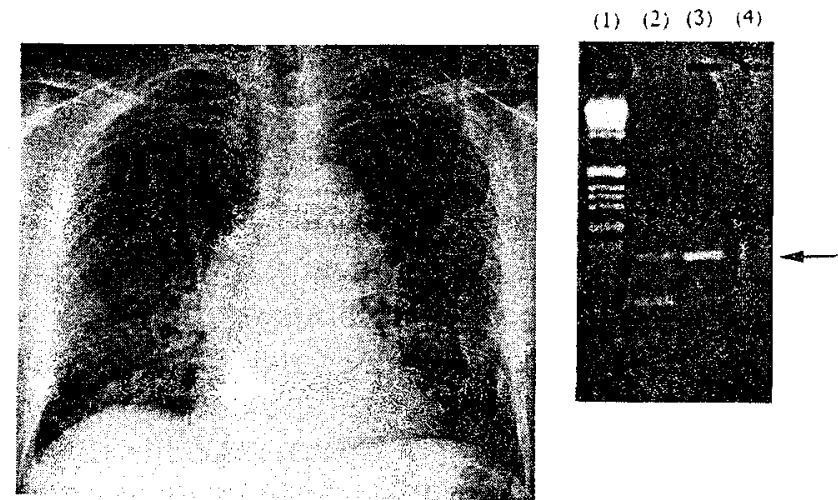

Fig. 3. DNA diagnosis of Pneumocystis carinii pneumonia.

(1) DNA size marker, (2) positive control, (3) sample from the patient, and (4) negative control. R. Kuboi with permission (First Department of Medicine, Kyushu University).

Table 7. Subjects on genetics addressed at the annual meetings of the Japan Society of Internal Medicine (1990-1996).

\begin{tabular}{cccc}
\hline Year & Number of subjects & $\begin{array}{c}\text { Percentage of subjects } \\
\text { related to genetics }\end{array}$ & $\begin{array}{c}\text { Percentage of subjects studied by } \\
\text { means of gene manipulations } \\
(\%)\end{array}$ \\
\hline 1990 & 554 & 9.2 & 5.6 \\
1993 & 757 & 18.4 & 7.1 \\
1996 & 756 & 25.4 & 11.2 \\
\hline
\end{tabular}

J Jpn Soc Intern Med, Vol. 79, 82, and 85 (special issues) [96].

Judging from these trends, the re-classification of microbes including virus, bacteria, rickettsia, chlamydia, mycoplasma, spirochete, treponema, and protozoan may be an important issue in the future, and the field of microbiology may change the entire aspects of knowledge and technology, if microbes can be adequately classified into families, species, and subspecies based upon moleculer phylogenetic trees which are usually made by a comparison of the base sequence in ribosomal RNA between microbes [92-95].

The method of polymerase chain reaction (PCR) has greatly contributed in these developmental processes [91].

Table 7 gives the number of subjects relevant to genetics which were presented in the past six years at the annual meetings of the Japan Society of Internal Medicine, the greatest society of clinical medicine in Japan. In 1996 the number of subjects on genetics has increased by three times compared to that in 1990 .

\section{Human hemoglobins and hemoglobinopathies}

Human hemoglobins have contributed remarkably to the overall understanding of the basic genetic principles and molecular basis of morbidity since the first 
such study by Ingram in 1956. Further studies of importance were the establishment and elucidation of the full amino acid sequence of the hemoglobin chains by Braunitzer et al. in 1961, and of the three-dimensional structure of mammalian heme proteins by Kendrew et al. in 1960 and Perutz in 1976 [97-99].

There are a number of reasons for this key role of hemoglobin, including the fact that it occurs in relatively accessible cells, in a relatively pure form, and in relatively large amounts [74]. In addition, the introduction of DNA technology into the study of hemoglobins has also resulted in the following progress:

The reticulocyte contains only globin mRNA, and therefore if this mRNA is exposed to reverse transcriptase it is possible to make a globin cDNA copy. The isolation of the hemoglobin mRNA has led to new insights into the gene structure and function. Restriction enzymes have been utilized for a refined analysis of the structure of hemoglobin genes [73, 100, 101].

Multigene family encoding the globin genes. The multigene family encodes the human globins, which will be discussed in Section 7. The $\alpha$-like globin genes are located as linked clusters on chromosome 16 , in order of $5^{\prime}-\xi-\psi \xi-\psi \alpha \alpha-\alpha 2-\alpha 1-\theta$ $3^{\prime}$, and the $\beta$-like globin genes on chromosome 11 , in order of $5^{\prime}-\varepsilon^{-G} \gamma^{-A} \gamma-\psi \beta-\delta-\beta$ $3^{\prime}$. The loci designated $\psi \alpha, \psi \beta$, and $\psi \xi$ are called pseudogenes which have a sequence homology with the $\alpha, \beta$, and $\xi$ genes but have mutations that prevent their expression $[102,103]$. It seems likely that they are evolutionary remnants of once active globin genes $[104,105]$.

Hemoglobin and the genetic code. Studies of human hemoglobins were thus able to quickly assess the adaptability of the genetic code. In 1969 Lehmann and Carrel examined the 95 amino acid substitutions known for human hemoglobins and first assessed the adaptability of the genetic code [106].

The phenomenon of split genes and RNA splicing in the globin genes. Shortly after the discovery of RNA splicing and split genes in an adenovirus by Sharp [107], Jeffreys and Flavell (1977) found in the $\beta$-globin of the rabbit that during transcription the precursor RNA derived from introns is excised and precursor RNA from non-contiguous exons is spliced together to form functional mRNA [108]. The same phenomenon was also ascertained in the human globin genes [109].

Almost all the genes in eukaryotes are split by introns, although in man there are few exceptions such as the genes for histones, interferons, mitochondrial genome, and the sex-determining gene, $S R Y$. The function of introns is not clear, but mutations within the introns may seriously affect RNA splicing and thereby interfere with correct gene synthesis [73]. There are a number of examples of such mutations in hemoglobinopathies (Table 9).

Discovery of restriction fragment length polymorphism. Jeffreys (1977) discovered in the region of $\beta$-like globins in man that variations occur as frequently as once in every hundred base pairs $[109,110]$. Since these variations are relatively frequent in the general population and are recognized by differences in

Vol. 42, No. 2, 1997 
the restriction fragment lengths, they were referred to as restriction fragment length polymorphism (RFLP). Such polymorphism has greatly contributed to advances in gene mapping.

Locus control region. Experiments involving the transfer of increasingly long segments of DNA into mouse embryos (transgenic mice) have revealed the need for a stretch of DNA, called a locus control region (LCR), upstream from the structural genes, in order to regulate the expression of the gene cluster correctly [111]. A type of $\gamma \beta$-thalassemia was also found to result from a deletion of this $\operatorname{LCR}[73,114]$.

The first attempt of prenatal diagnosis. Kan et al (1976) demonstrated by means of DNA technology that if the fetus was affected by $\alpha$-thalassemia, a disorder in which globin genes are deficient, then there was a reduced hybridization with an appropriate globin cDNA probe prepared from reticulocyte mRNA [112]. This thus represented a monumentary step in the field of prenatal diagnosis [73].

Molecular pathology of hemoglobinopathies and new genetics. A research area of approaches at the molecular level to the pathogenesis of unifactorial and multifactorial diseases was called "molecular pathology" by Perutz and Lehmann in 1968 [113], and the term "new genetics" was first used by Comings in 1979 for a novel approach in using DNA analysis for mapping the human genome [104].

By far the majority of visible mutations involve single base substitutions. In addition to these, various. kinds of other mutations have also been identified including deletion, insertion, duplication in the base sequence, premature termination, alteration of stop codon leading to elongation of globin chains, frame shift,

Table 8. Structural variants of hemoglobin with specific morbid conditions discovered in Japan.

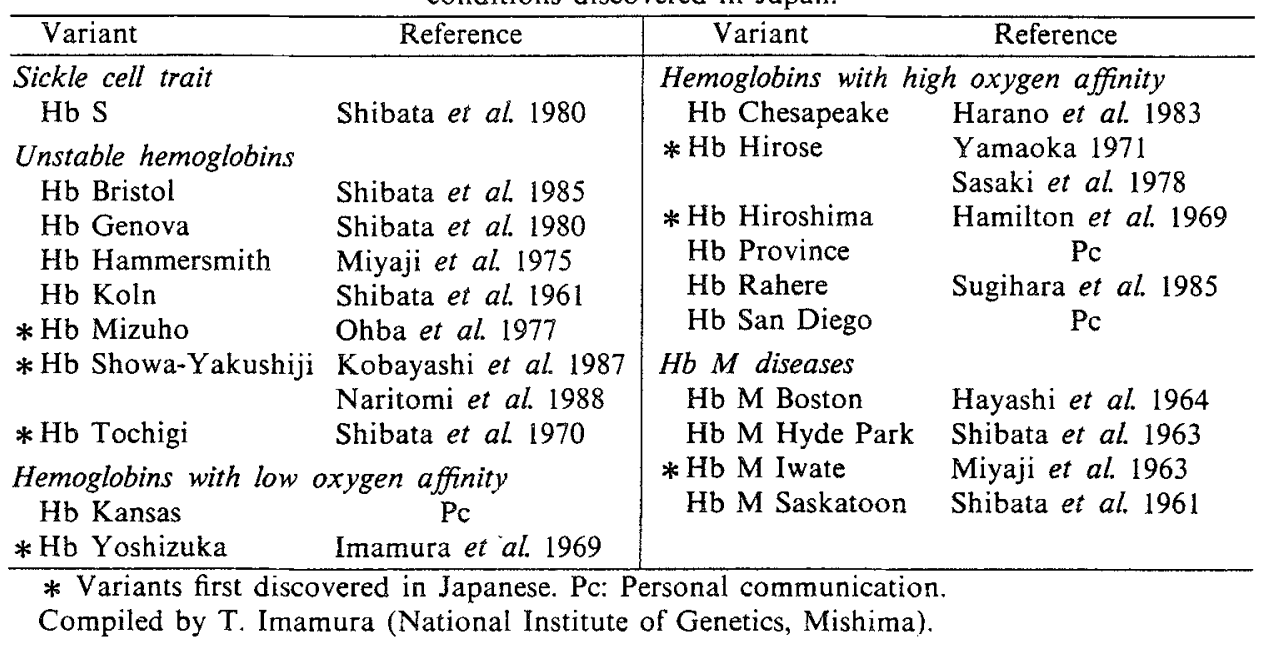


Table 9. Mutations in the thalassemias and allied conditions.

1. Deletion

Total deletion of the gene

Partial deletion of the gene

2. Mutations affecting translation

Nonsense mutations

Frameshift mutations

Initiation codon mutations

3. Mutations affecting transcription

Mutations in the CAC box

Mutations in the ATA box

Mutations in the GATA motif

Mutations in the cap site

4. Mutations affecting RNA processing

Mutations involving breakage at the 3 ' side of pre-RNA

Mutations affecting splicing

Mutations inactivating donor or acceptor sites

Mutations activating cryptic splice sites or creating new splice sites within exon or intron

5. Mutations affecting the post-translational process

Mutations inducing degradation of globin chains

Compiled by Y. Fukumaki (Institute of Genetic Information, Kyushu University).

unequal crossover, and fusion of genes, etc. These genomic changes resulted in a number of functional alterations and morbid conditions: modification of allosteric properties (hemoglobin variants with increased or reduced oxygen binding leading to polycythemia or cyanosis), reduced stability of the hemoglobin molecule (hemoglobin variants leading to hemolytic anemia).

The structural variants with specific morbid conditions discovered by Japanese investigators are listed in Table 8.

Table 9 gives a greater variety of mutations identified in the thalassemias and allied conditions which are characterized by defects in the sythesis of globin chains. Today, most of the conditions can be explained by point mutations or gene deletions that modify the output from a mutant locus [114-120].

There are two examples of particular interests among these variants: $\mathrm{Hb}$ Constant Spring and $\mathrm{Hb}$ Lepore. The former variant results from a mutation which eliminates the normal stop codon in $\alpha$-globin gene with the result that the $\alpha$-chain is unusually long and unstable, thus showing the clinical picture of $\alpha$-thalassemia [121]. Hb Lepore, which was first discovered by Gerald and Diamond in 1958 , showed the symptoms of $\beta$-thalassemia due to an unequal crossover between the $\beta$ - and $\delta$-globin loci [122]. Thereafter two examples of the opposite crossover products were discovered and called anti-Lepore hemoglobin: $\mathrm{Hb} \mathrm{P}$ Congo and $\mathrm{Hb}$ Miyada $[123,124]$. Since individuals of anti-Lepore hemoglobins possess a full set of normal $\beta$-globin genes, in addition to the $\beta-\delta$ fusion gene, $\beta$-chain synthesis is thus considered to be normal.

Vol. 42, No. 2, 1997 
Table 10. List of G6PD variants found in Japanese.

\begin{tabular}{|c|c|c|c|c|c|}
\hline Class* & Variant & Properties** & $\begin{array}{l}\text { Nucleotide } \\
\text { change }\end{array}$ & $\begin{array}{l}\text { Amino acid } \\
\text { change }\end{array}$ & $\begin{array}{l}\text { References and } \\
\text { remarks }\end{array}$ \\
\hline 1 & Tokyo & 1S:NNN:NNN:LN & $1246 \mathrm{G} \rightarrow \mathrm{A}$ & 416 Glu $\rightarrow$ Lys & $\begin{array}{l}\text { Hirono et al. } \\
1992\end{array}$ \\
\hline 1 & Wakayama & IS:NNL:N-N:LN & n.d. ${ }^{* * *}$ & n.d. & Miwa et al. 1978 \\
\hline 1 & Kurume & 1S:NNL:N-N:LB & n.d. & n.d. & Miwa et al. 1978 \\
\hline 1 & Fukushima & 1S:NNL:N-L:LN & $1246 \mathrm{G} \rightarrow \mathrm{A}$ & 416 Glu $\rightarrow$ Lys & Miwa et al. 1978 \\
\hline 1 & Yamaguchi & 1S:NHN:N-H:LS & $1160 \mathrm{G} \rightarrow \mathrm{A}$ & 387 Arg $\rightarrow \mathrm{His}$ & Miwa et al. 1978 \\
\hline 1 & Iwate & 1S:NHL:NNN:LN & $1160 \mathrm{G} \rightarrow \mathrm{A}$ & $387 \mathrm{Arg} \rightarrow \mathrm{His}$ & $\begin{array}{l}\text { Kanno et al. } \\
1988\end{array}$ \\
\hline 1 & Asahikawa & 1S:NHL:HNH:LB & $695 \mathrm{G} \rightarrow \mathrm{A}$ & 232 Cys $\rightarrow$ Tyr & $\begin{array}{l}\text { Beutler et al. } \\
1996\end{array}$ \\
\hline 1 & Niigata & 1S:NHL:HHL:LA & $1160 \mathrm{G} \rightarrow \mathrm{A}$ & $387 \mathrm{Arg} \rightarrow \mathrm{H}$ is & Chiba et al. 1989 \\
\hline 1 & Sendagi & 1S:LHN:H-H:LN & n.d. & n.d. & $\begin{array}{l}\text { Morisaki et al. } \\
\quad 1983\end{array}$ \\
\hline 1 & Kobe & 1S:HNN:NHH:LA & $1318 \mathrm{C} \rightarrow \mathrm{T}$ & 440 Leu $\rightarrow$ Phe & $\begin{array}{l}\text { Hirono et al. } \\
\quad 1994\end{array}$ \\
\hline 1 & Tsukui & 1S:HNN:N-L:LN & 3 base $\rightarrow$ del & $188 \mathrm{Ser} \rightarrow$ del & $\begin{array}{l}\text { Hirono et al. } \\
1995\end{array}$ \\
\hline 1 & Gifu & $1 \mathrm{~N}: N N N: N N H: L N$ & n.d. & n.d. & Fujii et al. 1984 \\
\hline 1 & Akita & $1 \mathrm{~N}: N N N: N-N: L N$ & n.d. & n.d. & Miwa et al. 1978 \\
\hline 1 & Kanazawa & IN:NNN:N-N:LB & n.d. & n.d. & Kitao et al. 1982 \\
\hline 1 & Ogikubo & IN:NNN:H-N:LN & n.d. & n.d. & Miwa et al. 1978 \\
\hline 1 & Yokohama & IN:NNL:N-N:LN & n.d. & n.d. & Miwa et al. 1978 \\
\hline 1 & Morioka & IN:NNH:NNH:LN & $1339 \mathrm{G} \rightarrow \mathrm{A}$ & 447 Gly $\rightarrow$ Arg & Endo et al. 1985 \\
\hline 1 & Sapporo & $1 \mathrm{~N}: \mathrm{NNH}: \mathrm{HHH}: \mathrm{LN}$ & n.d. & n.d. & Fujii et al. 1981 \\
\hline 1 & Tokushima & $1 \mathrm{~N}: \mathrm{NHN}: \mathrm{NNN}: \mathrm{LN}$ & n.d. & n.d. & Miwa et al. 1976 \\
\hline 1 & Kyoto & IN:HH-:--:LA & n.d. & n.d. & Kojima 1972 \\
\hline 1 & Nagano & 1F:LHL:NNN:LN & n.d. & n.d. & $\begin{array}{l}\text { Takahashi et al. } \\
\quad 1982\end{array}$ \\
\hline 1 & Fukuoka & IF:HNN:N-H:LB & n.d. & n.d. & Fujii et al. 1984 \\
\hline 1 & Heian & 1F:HH-:H-H:-B & n.d. & n.d. & $\begin{array}{l}\text { Nakai \& } \\
\quad \text { Yoshida } 1974\end{array}$ \\
\hline 1 & Shinagawa & $1-: H H-: N N N: L N$ & $1229 \mathrm{G} \rightarrow \mathrm{A}$ & 410 Gly $\rightarrow$ Asp & $\begin{array}{l}\text { Hirono et al. } \\
1994\end{array}$ \\
\hline 1 & Shinshu & 1-:HH-:NNL:NN & $527 \mathrm{~A} \rightarrow \mathrm{G}$ & 176 Asp $\rightarrow$ Gly & $\begin{array}{l}\text { Hirono et al. } \\
1994\end{array}$ \\
\hline 1 & Nara & 1-:-:---:L- & $953-976 \rightarrow$ del & $319-326 \rightarrow \mathrm{del}$ & $\begin{array}{l}\text { Hirono et al. } \\
\quad 1993\end{array}$ \\
\hline 2 & Onoda & $2 \mathrm{~S}: \mathrm{LN}-\mathrm{H}-\mathrm{H}: \mathrm{LB}$ & n.d. & n.d. & $\begin{array}{l}\text { Unpublished, } \\
\text { cited in Beutler } \\
\& \text { Yoshida } 1988\end{array}$ \\
\hline 2 & Ogori & $\begin{array}{l}\text { 2N:NNN:NNN: } \\
\text { NN }\end{array}$ & n.d. & n.d. & Miwa et al. 1977 \\
\hline 2 & $\begin{array}{l}\text { Mediterranean- } \\
\text { like }\end{array}$ & 2N:LL-HHH:LB & n.d. & n.d. & Miwa et al. 1977 \\
\hline 2 & Urayasu & 2F:NNL:NNN:NN & $281-283 \rightarrow$ del & 95 Lys $\rightarrow$ del & $\begin{array}{l}\text { Hirono et al. } \\
\quad 1995\end{array}$ \\
\hline 3 & Musashino & 3S:NLN:NHH:NN & $185 \mathrm{C} \rightarrow \mathrm{T}$ & 62 Pro $\rightarrow$ Phe & $\begin{array}{l}\text { Kuwakawa et al. } \\
1987\end{array}$ \\
\hline 3 & Kimiube & $3 N: N N N: N-N: N N$ & $1387 \mathrm{C} \rightarrow \mathrm{T}$ & $463 \mathrm{Arg} \rightarrow \mathrm{Cys}$ & $\begin{array}{l}\text { Nakatsuji \& } \\
\text { Miwa } 1979\end{array}$ \\
\hline
\end{tabular}




\begin{tabular}{|c|c|c|c|c|c|}
\hline Class* & Variant & Properties** & $\begin{array}{l}\text { Nucleotide } \\
\text { change }\end{array}$ & $\begin{array}{l}\text { Amino acid } \\
\text { change }\end{array}$ & $\begin{array}{l}\text { References and } \\
\text { remarks }\end{array}$ \\
\hline 3 & Hofu & 3N:LNN:NNH:NN & n.d. & n.d. & Miwa et al. 1977 \\
\hline 3 & Konan & 3F:NNN:N-N:NN & $241 \mathrm{C} \rightarrow \mathrm{T}$ & $81 \mathrm{Arg} \rightarrow$ Cys & $\begin{array}{l}\text { Hirono et al. } \\
1993\end{array}$ \\
\hline 4 & B & $\begin{array}{l}\text { 4N:NNN:NNN: } \\
\text { NN }\end{array}$ & & & Wild type \\
\hline 4 & Kiwa & 4F:NNN:N-N:NN & n.d. & n.d. & $\begin{array}{l}\text { Nakatsuji \& } \\
\text { Miwa } 1979\end{array}$ \\
\hline
\end{tabular}

* 1: associated with nonspherocytic hemolytic anemia; 2: severely deficient, less than $10 \%$ residual activity; 3 : moderately deficient, $10-60 \%$ residual activity; 4 : normal activity: $60-150 \%$; 5 : increased activity. ${ }^{* *}$ (class, electrophoresis: Km-G6P, Km-NADP, Ki-NADPH: 2deoxy-G6P, gal-6P, deamino-NADP: thermostability, pH-optimum); N: normal, H: high. L: low, B: biphasic, A: acidic. ${ }^{* * *}$ n.d.: not determined.

Compiled by A. Hirono (Okinaka Memorial Institute for Medical Research, Tokyo).

In addition to models of the mutation shown in the Tables 8 and 9 , there are also a number of unifactorial diseases due to new classes of pathogenic mutations which have been identified in the relatively recent past. These new classes of pathogenic mutations will be presented in Section 9.

\section{Glucose-6-phosphate dehydrogenase variants and nonspherocytic hemolytic anemia}

The discovery of X-linked variations of glucose-6-phosphate dehydrogenase (G6PD) followed the finding that a significant proportion of American Blacks develops acute hemolysis when they receive the synthetic antimalarial drug, primaquine [125]. It was shown that the hemolytic response to the drug was due to an intrinsic red cell abnormality, the red cell glutathione level was markedly decreased in primaquine sensitive individuals, and these were caused by a specific deficiency of the enzyme G6PD [126-128]. Since that time, a variety of variants of the enzyme G6PD have been identified biochemically.

In the early 1960s, the four alleles, $G d^{B}, G d^{A}, G d^{A-}$, and $G d^{\text {Mediterranean }}$ appeared to determine four structually distinct forms of the G6PD enzyme protein $[130,131]$. The B enzyme was regarded as the wild type, because it was the most common and occurred in all populations. The others possibly differed from it simply by single amino acid substitutions. Evidence on this point was demonstrated by Yoshida (1967): a particular asparagine residue presents in the B enzyme is replaced by an aspartic acid residue in the A enzyme [132]. In 1986, amino acid sequence of human G6PD was deduced from the cDNA sequence $[133,134]$. The tertiary structure of G6PD from Leuconostoc mesenteroides has recently been determined [135], and a model of the tertiary structure of the human enzyme has also been subsequently deduced [136].

Glucose-6-phosphate dehydrogenase variants. It became apparent almost immediately after the discovery of G6PD deficiency that the investigator was 
dealing not with a single mutation, but with a variety of genetic changes [129]. In 1967, a WHO study group recommended standardized methods of biochemical analysis, which have been followed by most investigators [137]. As a result, more than 400 different variants have so far been identified. On the other hand, the DNA mutations causing G6PD deficiencies have been analyzed since 1987 [138], and nearly 100 molecular variants have been reported so far [139]. Table 10 summarizes the variants found in Japanese, most of which were identified by Miwa and his associates [140]. Luzzatto and Metha (1995) commented as follows:

Molecular analyses have confirmed that the basis for G6PD deficiency is widely heterogeneous. In some cases, variants that had been assigned different names turned out to be identical; conversely, however, some variants that had been thought to be homogeneous have turned out to be heterogeneous on the moleculer level. Different mutants, each one having a polymorphic frequency, underlie G6PD deficiency observed in various parts of the world where this abnormality is prevalent. Genetic heterogeneity also explains, to a large extent, the diversity of clinical manifestations. Different mutations are responsible for the less common patients who have chronic hemolytic anemia and for the frequent patients who are only at risk of developing episodic hemolysis [129].

\section{Population genetics}

As a branch of biology, the origin of population genetics research goes back to Darwin's theory of evolution and Mendel's theory of inheritance which were synthesized with the biometrical methods developed by Pearson, Galton, and Weldon. It is well known that this synthesis was accompanied by the works of the great triumvirate, Fisher, Haldane, and Wright [13]. The present section focuses on four topics of population genetics relevant to human genetics.

Multigene families. Certain traits in man are controlled by several genes with related functions which occur either on the same chromosome, on two different chromosomes, or on several different chromosomes. For example, (1) the $\alpha$ interferon genes on chromosome 9 , and the major histocompatibility gene complex on chromosome 6, (2) $\alpha$ globin and $\beta$ globin are related to the gene loci of hemoglobin on chromosome 16 and 11 respectively (p. 277), and (3) argininosuccinate synthetase which is dispersed over at least eight autosomes and both sex chromosomes [73].

For a particular multigene family, different gene members within the same species show a much higher homology in amino acid and base sequences than those between different species. This mode of evolution is called coincidental evolution or concerted evolution which was first studied by Smith in 1974 [141]. Ohta $(1982,1983,1991)$ showed through statistical analyses of multigene families that concerted evolution can quantitatively be explained by repeated gene duplication, unequal crossover, and sometimes gene conversion [142-144].

Genetic distance. In 1953 Sanghvi proposed the concept of genetic distance 
in his study of the genetic differentiation of human populations, and the theoretical and practical approaches to this concept have further been developed by Cavalli-Sforza and Edwards (1967) [145, 146].

Harris and his associates (1966) made it possible to estimate the frequencies of alleles at a particular locus in human populations in a direct fashion with the advent of electrophoretic methods capable of being applied to a wide range of different enzymes and protein components [147]. This technical approach facilitated studies of genetic distance.

Among three models measuring genetic distance developed by Nei (1972), the standard genetic distance has widely been used particularly in the field of human genetics $[148,149]$. Table 11 shows the genetic distance $(D)$ between Caucasoids, Negroids, and Mongoloids which was estimated using Nei's formula. The genetic distance between Negroids and Mongoloids is slightly higher than that between Caucasoids and Negroids. On the other hand, the distance between Caucasoids and Negroids is the least among the three pairs of groups [149].

The neutral theory of moleculer evolution. The neutral theory of moleculer evolution was first proposed by Kimura in 1968. Using Haldane's theory of the cost of selection, Kimura estimated that the genetic load would be too large to maintain the entire human population if selection operated on the whole genome and he thus came to the conclusion that most mutations occurring in the genome would have to be selectively neutral or nearly neutral [150].

In 1969, King and Jukes in support of the neutral theory, independently proposed that non-Darwinian evolution is prevalent at the molecular level, showing that for protein-coding regions, nucleotide substitutions at the third codon positions take place more frequently than those at the second and first codon positions [151]. There have also been critics of the neutral theory and discussions on the neutral theory have thus developed into the so-called neutralist-selectionist controversy.

In 1971, Kimura and Ohta demonstrated clearly that moleculer evolution and genetic polymorphism can be explained in a unified way by the neutral theory, if genetic polymorphisms are regarded as an intermediate state during the stage in which a new mutation can proceed toward fixation in a population [152]. In 1976, Nei and his colleagues found support for the neutral theory in the results of

Table 11. Minimum, standard, and maximum estimates of number of net codon differences between Caucasoid, Negroid, and Mongoloid populations. A comparison using 35 common protein loci.

\begin{tabular}{lccc}
\hline & Caucasoid/Negroid & Caucasoid/Mongoloid & Negroid/Mongoloid \\
\hline Minimum & 0.014 & 0.010 & 0.017 \\
Standard & 0.017 & 0.011 & 0.019 \\
Maximum & 0.021 & 0.012 & 0.026 \\
\hline Nei \& Roychoudhury & $1974[149]$ &
\end{tabular}

Vol. 42, No. 2, 1997 
statistical analyses of a large amount of data on protein polymorphisms in a number of organisms including man [153]. In addition, Ohta proposed the slightly deleterious mutation theory as a modified extension of the neutral theory to successfully explain the observation that rare alleles were significantly in excess of that expected under the assumption of the neutral theory. She contended that most of the alleles which proceed to fixation are slightly deleterious rather than completely neutral [154].

Recent advances in DNA research have provided geneticists with substantial evidence supporting the neutral theory. First of all, Miyata et al. (1980) demonstrated that synonymous substitutions take place at a much higher rate than nonsynonymous substitutions. This indicates that a mutation that does not lead to an amino acid substitution is a neutral mutation at least at the protein level [155]. More crucial support for the neutral theory was provided by Li et al. and Miyata and Yasunaga in 1981. They showed that the rate of nucleotide substitutions in pseudogenes were the highest among the genes examined. Since pseudogenes are replicas of active genes but do not yield a recognizable gene product, the evolution of pseudogenes may thus be regarded as a paradigm of neutral evolution [156, 157]. Furthermore, the neutral theory is also supported by observations that the extremely high rates of nucleotide substitution in RNA viruses cannot be explained by strong positive selection but rather by an extremely high mutation rate [158].

The neutral theory has been accepted by many investigators, but further studies are still needed to elucidate how many loci evolve in a manner that departs from the neutral theory $[159,160]$.

Studies to determine spontaneous and induced mutation rates in human germ cells. After extensive epidemiological studies of the children of atomic bomb survivors which have yielded no statistically significant increases in the genetic effects compared to a control population [161], beginning in 1976, an approximately 10 year investigation to detect germ cell mutations at the protein level was carried out. Two groups of children, that is, 11,364 children of the exposed parents in which the combined parental gonadal dose of each child was 0.01 Sievert (Sv) or more (exposed group), and 12,297 control children in which the combined parental dose was less than $0.01 \mathrm{~Sv}$, were examined for rare (allele frequency is less than 0.01 ) electrophoretic variants of 30 blood proteins; 10,000 of these children were also screened for enzyme-deficiency ( $66 \%$ or less of the mean normal enzyme activity) variants of nine erythrocyte enzymes. In addition to approximately 1,200 inherited variants, three mutants in the exposed group, and four in the control group were detected. No statistically significant difference was observed between the mutation rate of the exposed group and that of the control group [162-165]. It is possible, however, that the number of loci screened for mutations might not have been large enough to allow detection of any radiationinduced mitations. 
Recently, the feasibility of detecting radiation-induced mutations at the DNA level has been explored. To serve as a source of cells for future screening, cell lines have been established from the peripheral B lymphocytes of 800 families composed of father-mother-child trios from the exposed and the control groups.

For detection of deletion/insertion/rearrangement (D/I/R) types of mutations, which are believed to predominate among radiation-induced mutations, repetitive sequences such as minisatellites and microsatellites are being examined in a pilot study. A subsample of the 800 families, composed of 50 exposed families and 50 control families are being used. Preliminary results show that 58 mutations were detected in a total of 124 children. These germ cell mutations, however, showed no evidence of being induced by radiation [166-168]. Two dimensional gel electrophoresis of DNA, which has been shown to be suitable for screening for $\mathrm{D} / \mathrm{I} / \mathrm{R}$ mutations in single copy sequences [169], will also be employed in the pilot study. With these techniques, frequencies of spontaneous and induced mutations at various parts of DNA in human germ cells will be obtained at the DNA level.

\section{Entities of hereditary disease, inborn error of metabolism, and congenital abnormality established by Japanese investigators}

Tables 12 and 13 show the entities of hereditary disease, inborn error of metabolism, and congenital abnormality which have been established by careful and sharp-sighted observations of Japanese investigators in the relatively recent

Table 12. Inborn errors of metabolism discovered by Japanese investigators (1949-1994).

\begin{tabular}{ll}
\hline \multicolumn{1}{c}{ Disease entity } & Investigator \\
\hline Acatalasemia & Takahara \& Miyamoto 1949 \\
Pyruvate kinase deficiency & Tanaka KR et al. 1962 \\
Formiminotransferase deficiency & Arakawa et al. 1965 \\
Glycogen disease type VII & Tarui et al. 1965 \\
Isovaleric aciduria & Tanaka K et al. 1966 \\
GMl-gangliosidosis & Okada \& O'Brien 1968 \\
GM2-gangliosidosis & Okada \& O'Brien 1969 \\
Nonketotic hyperglycinemia type I & Tada et al. 1969 \\
Globoid cell leukodystrophy & Suzuki \& Suzuki 1970 \\
Hereditary progressive dystonia & Segawa et al. 1976 \\
& Ichinose et al. 1994 \\
Glycogen disease type IB & Narisawa et al. 1978 \\
Nonketotic hyperglycinemia type III & Hayasaka et al. 1983 \\
Tyrosinemia type III & Endo et al. 1983 \\
Methylglutaconic aciduria & Narisawa et al. 1986 \\
Cerebrohepatorenal syndrome & Shimozawa et al. 1992 \\
Hereditary motor and sensory neuropathy type I & Hayasaka et al. 1993 \\
Dentatorubral-pallidoluysian atrophy & Koide et al. 1994 \\
& Nagafuchi et al. 1994 \\
Machado-Joseph disease & Kawaguchi et al. 1994 \\
\hline
\end{tabular}

Vol. 42, No. 2, 1997 
past. Among these, four unique disorders are outlined here.

Muscle phosphofructokinase ( $P F K$ ) deficiency. Muscle PFK deficiency described first by Tarui and his associates in 1965 was classified as type VII glycogenesis, and no controversy has hitherto occurred concerning the eponym [170]. This is a clinical entity first demonstrated among the enzyme defects in muscle glycolysis, if the word of "glycolysis" is used separately from "glycogenolysis." This disease entity has also been added to the group of enzymopenic hemolytic diseases. Among eight clinical entities of hepatic and muscle glycogenosis, in addition, the causal genetic lesion was first demonstrated by Tarui and his associates in 1990 by an analysis of muscle PFK deficiency.

It is unparalleled that this individual research group was able to not only establish a novel clinical entity but also to demonstrate the causal defective enzyme, the thorough pathophysiology, to succeed in cDNA cloning of the normal human enzyme, and to identify gene structure for the normal enzyme and the responsible several genetic defect [171].

Nonketotic hyperglycinemia (NKH). NKH is an autosomal recessive disorder characterized by abnormally high concentrations of glycine in plasma and cerebrospinal fluid, causing severe brain damage in the early stages of life. In 1969 Tada and his associates demonstrated that the primary defect is in the glycine cleavage system, which consists of four protein components: $P, H, T$, and $L$. This research group revealed that the majority of $\mathrm{NKH}$ patients had a specific defect in P-protein (type I), some patients had a specific defect in T-protein (type II), while one patient had a specific defect in H-protein [172, 173].

The cDNA encoding human $\mathrm{P}$ - and $\mathrm{T}$-protein respectively, and the molecular lesions at the DNA level were elucidated in the patients with NKH. Based upon these results, Tada pointed out that the glycine cleavage system is a physiologically

Table 13. Hereditary diseases and congenital abnormalities discovered by Japanese investigators (1960-1988).

\begin{tabular}{ll}
\multicolumn{2}{c}{ Dapanese investigators (1960-1988). } \\
\hline * Fukuyama congenital muscular dystrophy & Investigator \\
Cerebro-oculo-hepato-renal syndrome & Arima et al. 1971 \\
* Conotruncal anomay face syndrome & Takao et al 1980 \\
Kabuki make-up syndrome & Kuroki et al. 1981 \\
& Niikawa et al. 1981 \\
* EEM syndrome & Ohdo et al. 1983 \\
* Tricho-rhino-phalangeal syndrome type III & Sugio \& Kajii 1984 \\
Ohdo blepharophimosis syndrome & Ohdo et al. 1986 \\
TAEDLD abnormalities & Ohdo et al. 1987 \\
Sonoda syndrome & Sonoda et al. 1988 \\
Cryptomicrotia-brachydactyly syndrome & Tonoki et al. 1988 \\
\hline
\end{tabular}

* Modes of inheritance were determined. EEM syndrome: Ectodermal dysplasia, ectrodactyly, and macular dystrophy, TAEDLD abnormalities: Tetra-amelia with ectodermal dysplasia and lacrimal duct abnormalities. 
major pathway of glycine catabolism in man and other mammals, and this system thus plays an important role in regulating the concentrations of glycine in the brain which is neurotoxic when excessively produced [173].

Fukuyama congenital muscular dystrophy (FCMD). Fukuyama congenital muscular dystrophy (cerebromuscular dystrophy; Fukuyama type) is an autosomal recessive disorder which was first described by Fukuyama and his colleagues in 1960 [174]. This disease entity is clinically characterized as follows: (1) an early onset in infancy, usually before the age of 9 months, (2) muscle hypotonia and weakness in infancy, (3) wasting of the muscles and contracture of the joints gradually developing towards the later stages, particularly involving the proximal muscles, (4) myopathic facies, (5) pseudohypertrophy of calf muscles and febrile or non-febrile convulsions (in approximately $50 \%$ of the cases), (6) mental retardation with speech disturbance, etc [174].

All available examinations of skeletal muscles revealed changes which were essentially identical with those in Duchenne type of muscular dystrophy. Neuroimaging technologies and autopsies of more than 50 cases undertaken in Japan also results in new insights onto malformation in the brain including a remarkable malformation of cobblestone lissencephaly (polymicrogyria and pachygyria), brain stem dysplasia, etc.

The gene responsible for the development of FCMD is located on chromosome 9 (9q31-33) [175].

Kabuki make-up syndrome. This congenital abnormality is a causally unknown multiple congenital anomaly/mental retardation syndrome which was independently described by Kuroki et al. and Niikawa et al. in $1981[176,177]$.

Most affected individuals had five cardinal manifestations: (1) a peculiar facial expression characterized by an eversion of the lower lateral eyelids, arched eyebrows with sparse or dispersed lateral one-third, depressed nasal tip, and prominent ears, (2) skeletal anomalies including brachydactyly $\mathrm{V}$ and spinal deformity with or without sagittal cleft vertebrae, (3) mild to moderate mental retardation, (4) postnatal growth disturbance, and (5) dermatoglyphic abnormalities. Various complications were observed including congenital defects in the cardiovascular system, early breast development in infantile females, cleft lip and/ or palate, recurrent otitis media in infancy, renal/urinary tract anomalies, seizures with abnormal EEG findings.

Five familial cases have been accumulated so far. In addition, an autosomal dominant mode of inheritance with variable expressivities has also been proposed at the present time $[176,177]$.

\section{New classes of pathogenic mutation}

In the 1980s and 1990s a number of new classes of pathogenic mutation have successively been identified, which differed from the hitherto known mutational changes in the structural genes on chromosomes (Table 14). The following 
Table 14. New classes of pathogenic mutation.

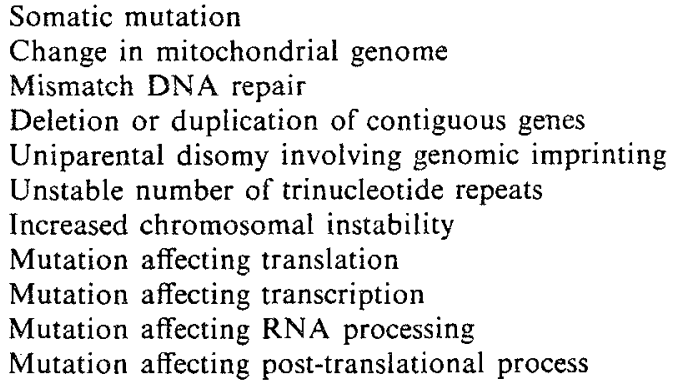

unifactorial diseases may be pointed out as such examples: paroxysmal nocturnal hemoglobinuria due to somatic mutation, Kearns-Sayre syndrome due to a change in mitochondrial genome, a type of Xeroderma pigmentosum due to mismatch repair as copy editing for errors that have occurred during replication, contiguous gene syndrome due to deletion or duplication of contiguous genes, Prader-Willi syndrome due to uniparental disomy (genomic imprinting), neurodegenerative diseases and fragile $X$ syndrome due to unstable number of trinucleotide repeats, Bloom syndrome due to increased chromosomal instability, and thalassemias and allied conditions due to mutations affecting translation, transcription, RNA processing, and post-translational process.

Among these deseases, two examples are herein outlined.

Paroxysmal nocturnal hemoglobinuria (PNH). In 1964 Ross and Rosenbaum suggested that PNH might be a disease due to somatic mutation because of the presence of two red cell populations [179].

Many eukaryotic proteins bind to the cell membrane by a glycosyl phosphatidylinositol (GPI) anchor. Kinoshita and his associates demonstrated that the biosynthesis of GPI anchor is deficient in the abnormal blood cell populations of this disease. A deficiency in the surface expression of GPI-anchored complement inhibitors leads to complement-mediated hemolysis. The PIGA gene responsible for the biosynthesis of the GPI anchor lies on chromosome $X$, and the mutant $P I G A$ gene accounts for the expression of $\mathrm{X}$-linked recessive phenotype of somatic mutation. The somatic mutation must occur in the hematopoietic stem cell because the abnormal cell population appears in all blood cell lineages. These mutations tend to vary among the affected individuals and are usually small, involving one or two bases $[180,181]$.

Dentatorubral and pallidoluysian atrophy (DRPLA). This neurodegenerative disease entity, DRPLA, is an autosomal dominant disease which was first described by Koide et al. and Nagafuchi et al. independently in 1994 (Table 12). DRPLA is characterized by the combined degeneration of the dentatorubral and pallidoluysian systems, showing a combination of symptoms including cerebellar 
ataxia, myoclonic epilepsy, choreoathetosis, and dementia. The affected individuals possess an expanded CAG trinucleotide repeat in a gene on the short arm of chromosome 12. The size of repeats varied from 7 to 23 in normal individuals, but in affected individuals one allele was expanded to 49-57 repeats or occasionally even more. Expansion was usually associated with paternal transmission and only occasionally with maternal transmission. The size of the repeats showed a close correlation with the age of onset and severity of the disease. The expansion of the triplet repeats accounted for a number of clinical characteristics such as the phenomenon of anticipation and a wide variety of clinical manifestations of the disease $[182,183,186]$.

Yazawa et al. (1995) identified the DRPLA gene product in normal human brains as a $\approx 190 \mathrm{kD}$, and in DRPLA brains as a larger $\approx 205 \mathrm{kD}$ [184].

Segregation distortion. In experimental organisms, segregation ratios deviating from those expected from simple Mendelian inheritance were occasionally observed. An example of selection in gametogenesis is found in Drosophila. The segregation-distorter $(S D)$ locus has two known alleles. Normal segregation of chromosomes occurs with the wild-type allele. Males heterozygous for the mutant allele, under certain conditions of environment, show among progeny a marked departure from the expected $1: 1$ ratio in favor of the $S D$ allele. This interaction of homologous genes during meiosis is called meiotic drive [74].

Relatively well-documented human examples of such an unusual segregation suggesting prezygotic selection may be congenital aniridia and Alport's syndrome which were reported by Shaw et al. in 1960 and Fuhrmann in 1963 respectively [187, 188]. Since that time, no particularly significant evidence for meiotic drive has been demonstrated for a long time. In 1990s, however, disease cases showing marked segregation distortion have successively been reported: retinoblastoma, cone-rod retinal dystrophy, split hand/split foot disease, myotonic dystrophy, DRPLA, and Machado-Joseph's disease [189-192].

In segregation analysis of DRPLA, Tsuji and his associates noted that the segregation ratios of mutant gene and wild-type gene of DRPLA were not equal in case of paternal transmission. However, such a distortion in segregation was not

Table 15. Segregation distortion observed in family data of DRPLA.

\begin{tabular}{ll|ccc|cc}
\hline \multirow{2}{*}{ Parent of origin } & \multirow{2}{*}{$\begin{array}{c}\text { Affected } \\
\text { individuals }\end{array}$} & $\begin{array}{c}\text { Unaffected } \\
\text { individuals }\end{array}$ & $\begin{array}{c}\text { Total } \\
\text { individuals }\end{array}$ & \multicolumn{2}{c}{ Statistical test } \\
\cline { 6 - 8 } Male & Number & 78 & 47 & 125 & & $p$ \\
& $\%$ & $63 \%$ & $37 \%$ & & 7.7 & $p<0.01$ \\
& M/F ratio & 37.4 & 27.2 & 64.6 & & \\
\hline \multirow{3}{*}{ Female } & $\%$ & 36 & 50 & 86 & & \\
& Number & $42 \%$ & $58 \%$ & & 2.3 & $0.1<p<0.2$ \\
& M/F ratio & 22.1 & 24.3 & 46.4 & & \\
\hline Number of total sample & 114 & 97 & 211 & 1.4 & $0.2<p<0.3$ \\
\hline
\end{tabular}

$\mathrm{M} / \mathrm{F}$ ratio: Male to female ratio. Ikeuchi et al. 1996 [185].

Vol. 42, No. 2, 1997 
observed in case of maternal transmission (Table 15). These data suggest that the phenomenon of meiotic drive possibly occurs in man as well.

\section{Genomic rearrangements}

DNA segments in the human genome can move into new genomic locations or amplify themselves. Such genomic rearrangements may also have some effect on the expression of affected genes.

Some genomic rearrangements are unprogrammed, occurring randomly and thus have no physiological significance, such as transposon and movable genetic elements [193]. In some instances, however, they may cause mutations, modify the expression of the genes, or render tumor cells drug resistance by gene amplification. Others are programmed events that play a critical role in the control of expression of some genes during differentiation and the development of certain cell types.

Hozumi and Tonegawa (1976) first demonstrated that immunoglobulin genes rearrange during the development of B-cells. Variable regions of immunoglobulins are encoded by variable, diverse and joining gene segments that are located separately in the germ cell line, but brought together in B-cells by rearrangement. This mechanism generates the diversity of immunoglobulins required for recognizing almost unlimited number of foreign antigens $[194,195]$.

Honjo and Kataoka (1978) demonstrated that class switching and the successive change of immunoglobulin heavy chain also occur by gene rearrangements $[196,197]$.

Mak, Davis and their colleagues (1984) isolated genes encoding T-cell receptors, which possess the gene structure and strategy similar to those of immunoglobulins to create their diversity $[198,199]$.

The programmed genomic rearrangements are only known to occur in these antigen receptor genes of the immune system in man, but similar mechanisms can also conceivably operate in other cell types such as neural cells in the central nervous system where a great diversity may exist [200].

Allelic exclusion. During T-cell development, the site-specific DNA rearrangements mediating the assembly of $\beta$ - and $\alpha$-chain of the T-cell receptor are developmentally ordered. In particular, the assembly and expression of a complete $\beta$-chain gene blocks further rearrangements at the $\beta$-locus [201]. Such a phenomenon is referred to as allelic exclusion which is also observed in the process of rearrangements of immunoglobulins.

\section{Approaches to multifactorial traits}

Common diseases are mostly multifactorial. Such diseases are still not easy to analyze from genetic viewpoint, though Fisher showed, in a classical paper published in 1918, that such a mode of inheritance is an extension of, and not contrary to Mendelian concepts concerning unifactorial inheritance [15]. 
Table 16. Approaches to multifactorial traits in the years 1949-1965.

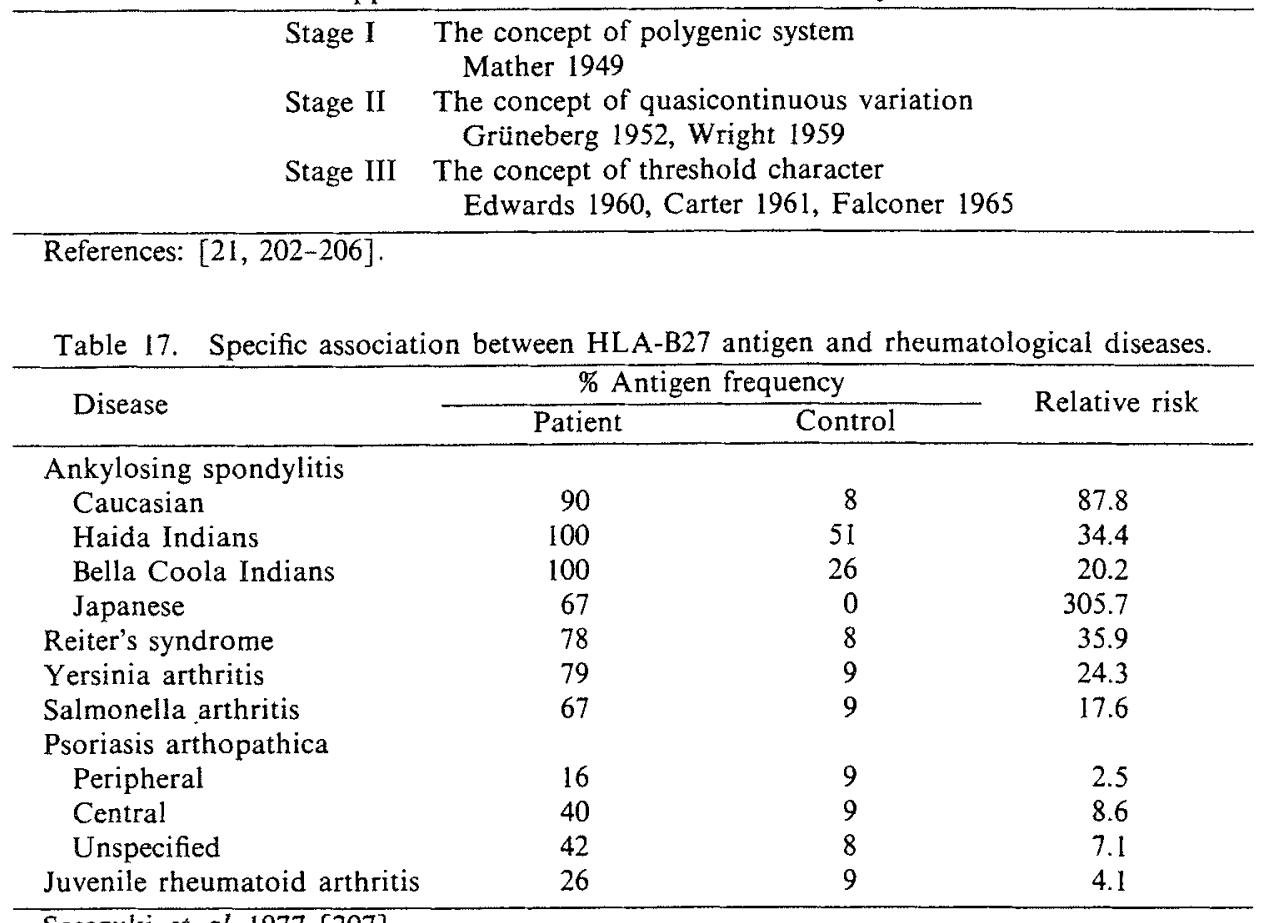

Sasazuki et al. 1977 [207].

A. Developmental process of genetic approaches to multifactorial traits.

Genetic approaches to such multifactorial traits explored principally by English geneticists may chronologically be divided into three stages as shown in Table 16, and have now entered a fourth stage. The initiative of the fourth stage was the demonstration of association of a given trait with certain types of polymorphic traits.

$H L A$ and disease association. The strongest HLA and disease association is that between ankylosing spondylitis and HLA-B27 antigen. As shown in Table 17, more than $90 \%$ of Caucasian patients with ankylosing spondylitis possess B-27, whereas only $5-9 \%$ of the controls possess this specificity. This strong association is also prominent in other ethnic groups. In Japanese, in whom B-27 antigen is extremely rare, ankylosing spondylitis again has a strong association with B-27 [207]. This means that the $H L A-B 27$ gene is major or submajor gene having pleiotropic effects on liabilities to rheumatological diseases as well as gene responsible for the production of HLA-B27 antigen. Such an approach is thought to be the starting point in the fourth stage.

$B$. Adult diseases

The adult diseases subjected to analysis in the recent past include the follow- 
Table 18. Comparison of concordance for schizophrenia in MZ ad DZ twins.*

\begin{tabular}{llccccc}
\hline & \multicolumn{5}{c}{ Investigator } \\
\cline { 2 - 7 } & $\begin{array}{c}\text { Kallman } \\
1946\end{array}$ & $\begin{array}{c}\text { Slater } \\
1961\end{array}$ & $\begin{array}{c}\text { Inouye } \\
1961\end{array}$ & $\begin{array}{c}\text { Kringlen } \\
1967\end{array}$ & $\begin{array}{c}\text { Allen } \text { et al. } \\
1972\end{array}$ \\
\hline \multirow{2}{*}{$\mathrm{MZ}$ No. of pairs } & 174 & 41 & 55 & 55 & 95 \\
& Concordance ** (\%) & $69-86$ & $68-76$ & $60-76$ & 25 & 27 \\
\hline \multirow{2}{*}{$\mathrm{DZ}$ No. of pairs } & 517 & 115 & 17 & 172 & 125 \\
\cline { 2 - 7 } Concordance** (\%) & $10-15$ & $11-14$ & $12-22$ & 4 & 5 \\
\hline $\mathrm{MZ} / \mathrm{DZ}$ ratio & 5.7 & 5.4 & 3.5 & 3.8 & 5.7 \\
\hline
\end{tabular}

*A fuller summary of twin studies is given in Allen et al. (1972), from which information in the above table was taken. ** The second figure is corrected for age. Sutton 1975 [74].

ing: diabetes mellitus, hypertension, obesity, neoplasma, osteoporosis, atherosclerosis, coronary heart disease, rheumatoid arthritis, atopic disease, allergic disease, inflammatory diseases of the intestine including Crohn's disease and ulcerative colitis, Alzheimer's disease, manic depressive illness, schizophrenia, alcohol dependency, etc.

Mental and psychiatric disorders. It is noteworthy that analyses have recently been directed toward mental and psychiatric disorders such as schizophrenia, manic depressive illness, Alzheimer's disease, and alcohol dependency which were previously thought to be out of reach regarding a determination of the pathogenesis.

In the case of schizophrenia, twin, family, and adoption studies have formed the basis of evaluation of the relative importance of genetic and nongenetic factors in the etiology $[74,208-211]$. Several of the larger studies on twins are summarized in Table 18. These studies consistently show higher concordance rates for monozygotic twins as compared to dizygotic twins [74, 208, 209].

In a study of five Icelandic and two English families, with a total 39 cases of schizophrenia, evidence of linkage to RFLP markers for the chromosome 5q11-13 region was found [212]. However, an even more detailed analysis of this chromosomal region, schizophrenics showed no evidence whatever for linkage to this region. More recent studies have also failed to confirm this linkage [104].

Alzheimer's disease, on the other hand, is a representative example of mental and psychiatric disorders in which some progress has been seen. A combination of approaches has been used, including the rare example of families in which the disease appears to show a pattern of simple inheritance, cloning and analysis of candidate gene in pathways and the association of particular forms of a candidate gene with the morbid condition more often than expected under randomness [213]. A series of studies have thus started with great potentialities toward the future.

Diabetes mellitus. Diabetes mellitus is genetically and pathophysiologically heterogeneous, but there are at least two major types: insulin-dependent diabetes mellitus (IDDM) and non-insulin-dependent diabetes mellitus-(NIDDM). Twin 


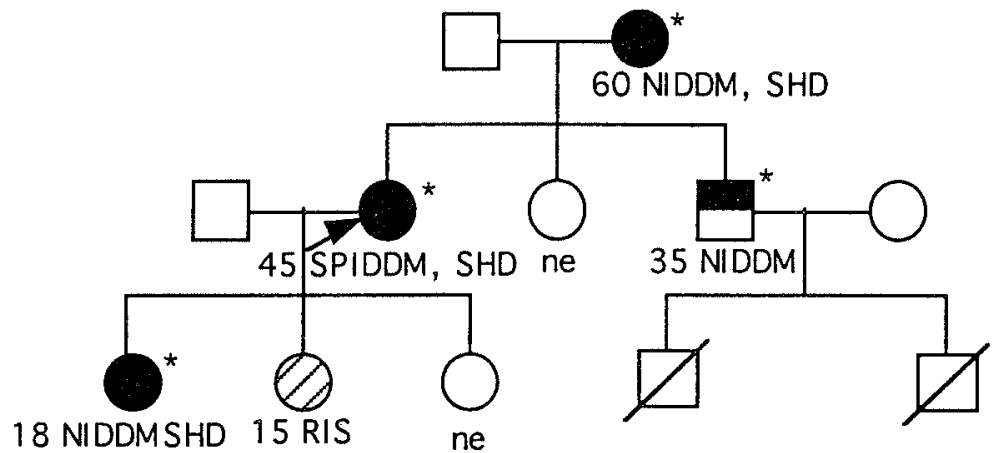

Fig. 4. A pedigree of mitochondrial diabetes mellitus (MIDD).

* Single base substitution at position 3243. SHD: sensory hearing disturbance, SPIDDM: slowly progressive IDDM, RIS: reduction of insulin secretion, ne: not examined. Kadowaki 1996 [219].

studies have suggested that hereditary factors play an important role in the both types, though they appear to be of much greater significance in NIDDM [214]. Most of IDDM and NIDDM are probably multifactorial, but changes in a few genes have been detected. The present section focuses only on such single-genedetermined entities of NIDDM on the basis of recent studies in Japan.

It was demonstrated that the secretion of a structurally abnormal insulin with a defective function (Insulin Wakayama) resulted in NIDDM, and that mutation in the insulin receptor gene causes also NIDDM due to impaired actions of insulin [215-217].

Oka et al. (1993) and Kadowaki et al. (1993) identified that single base substitution (an $A$ to $G$ transition) in the mitochondrial gene for tRNA [Leu(UUR)] at position 3243 causes NIDDM due to impaired insulin secretion to glucose [218-220]. This mitochondrial diabetes mellitus was maternally transmitted and often associated with sensorineural hearing disturbance. A family with this type of diabetes is shown in Fig. 4, where members showing slowly progressive IDDM and reduced insulin secretion are found [219]. This entity was thus called "maternally inherited diabetes and deafness" (MIDD), presumably comprising about $1 \%$ of all diabetics in Japan $[218,220]$.

Three genes are involved in the pathogenesis of maturity-onset in the young (MODY): genes for hepatocyte nuclear factor- $4 \alpha$, glucokinase, and hepatocyte nuclear factor- $1 \alpha$ which were designated as MODYl gene, MODY2 gene, and $M O D Y 3$ gene, respectively [221-225]. These are all thought to be responsible for the impairment of glucose-induced insulin secretion from $\beta$-cells of the pancreas.

\section{Human cancer genetics}

Numerous discoveries have been made on the molecular basis of oncogenesis 
in man since the discoveries of the chicken sarcoma by Fujinami and Inemoto in 1910 and the sarcoma virus by Rous in 1911 [227, 228]. However, it is impossible to cover the whole subjects here in any depth. This section thus only outlines the major studies relevant to human cancer genetics.

Four categories of human cancers classified by conditions of familial occurrence. In discussing the role of hereditary and environmental factors in tumorigenesis, it is useful to classify human cancers into four categories: (1) rare genetic forms of cancer, (2) inherited common cancers, (3) cancer-prone families, and (4) common cancers [73].

The third category has been largely defined by Lynch as an autosomal dominant trait, tumors developing usually before the age of 40 , and there are often multiple primary tumors at the sites of more than two organs [229]. At present this concept appears to be widely accepted, although it is still difficult to distinguish the apparent cancer-prone families from a familial aggregation of common cancers which could occur by chance [73].

Table 19. Major studies corresponding to milestones in human cancer genetics.

Discovery of Philadelphia chromosome and its chromosomal basis Nowell \& Hungerford 1960, Rowley 1973

Two hit hypothesis in tumorigenesis: $R B$ gene

Knudson 1971, Cavenee et al. 1983

First recognition of human neoplasma due to a retrovirus-adult T-cell leukemia Takatsuki et al. 1973, Poiesz et al. 1980, Miyoshi et al. 1979, Hinuma et al. 1981, Yoshida et al. 1984

Identification of oncogene Shih \& Weinberg 1982, Goldfarb et al. 1982, Parada et al. 1982, Santos et al. 1982, Reddy et al. 1982

Identification of proto-oncogene Stehlin et al. 1976, Takeya \& Hanafusa 1983

Identification of tumor suppressor gene

$R B$ gene

Friend et al. 1986

p.53 gene

Lane \& Crawford 1979, Linzer \& Levine 1979

$A P C$ gene

Joslyn et al. 1991, Nishisho et al. 1991

$B R C A 1$ gene

Miki et al. 1994

Association between growth factor and cancer

Doolittle et al. 1983, Waterfield et al 1983, Downward et al. 1984

Signal transduction involving protein phosphorylation

Collet \& Erikson 1978

Apotosis and cancer

Tsujimoto et al. 1984, Itoh et al. 1991

References: $[69,226,230-257]$. Compiled by J. Miyoshi (Takai Biotimer Project, ERATO/ JST, Ohsaka). 
Major studies corresponding to milestones in human cancer genetics. Table 19 lists the major studies corresponding to milestones in human cancer genetics which were conducted from 1960 to 1995 [226, 230].

Philadelphia chromosome. In a few neoplasias, a single specific chromosomal aberration limited to the tumor tissue has been described. The classic example is the Philadelphia chromosome discovered by Nowell and Hungerford in 1960 , which is almost regularly associated with chronic myelogenous leukemia [69]. In 1973 Rowley identified that this chromosome occurs due to a reciprocal translocation between chromosome 22 and chromosome 9, with the break-point being in $9 \mathrm{q} 34$ and $22 \mathrm{q} 11$ respectively [231].

Retinoblastoma and the "two-hit" hypothesis. Most unilateral cases of retinoblastoma, a malignant tumor of the eye, are sporadic, but bilateral cases are often familial $[232,233]$. In the latter cases the tumor occurs due to two mutational steps at the $R B$ locus which is located on the long arm of chromosome 13 (13q14). Tumor formation only results when a second, and this time somatic mutation occurs in a retinal cell at the $R B$ locus on the other homologous chromosome. In the former sporadic cases both first and second mutations occur in the same retinal cell. This "two-hit" hypothesis was proposed by Knudson in 1971 , which accounts also for some cancers of familial occurrence [73, 233].

The first human neoplasma due to a retrovirus-adult T-cell leukemia. Around the year 1973, Takatsuki and his associates recognized the existence of adult T-cell leukemia (ATL), previously a disease of unknown entity [234]. A series of subsequent studies revealed this disease entity to be the first human neoplasma due to a retrovirus.

HTLV (human T-cell leukemia virus) corresponding to the pathogen of ATL was first reported by Gallo and his associates in 1980 [235]. They isolated HTLV from cultured cells taken from a patient with an aggressive variant of Mycosis fungoides and from another patient with Sézary's syndrome [234, 235]. Both diseases have been said to have cutaneous T-cell lymphoma, but they also showed some unusual features which, in retrospect, link them to the clinical entity of ATL. In Japan, the coculturing of ATL cells with umbilical cord blood lymphocytes was first done by Miyoshi et al. who obtained the cell line MT-1 [236]. Hinuma et al. demonstrated that ATL patients possess antibodies against presumed viral antigens on MT-1 cells [237]. Shortly after these studies, a retrovirus was isolated and named ATLV. Since Yoshida et al. showed that HTLV and ATLV are identical, the term "HTLV-1" (human T-lymphotropic virus type I) has commonly been used [238].

Identification of oncogene, proto-oncogene, and tumor suppressor genes. In 1982 , a point mutation in a cellular oncogene was first reported independently by Weinberg and his associates, Wigler and his associates, and Barbacid and his associates in their studies of oncogene $\mathrm{c}-\mathrm{H}-$ ras in human urinary bladder cancer [239-243].

Vol. 42, No. 2, 1997 
Thereafter, two types of cancer-causing genes were recognized: proto-oncogenes and tumor suppressor genes. These are responsible for proteins whose normal function is to suppress uncontrolled cell growth and their inactivation results in the normal control being lost $[244,245]$. Further studies have revealed the phenomenon called LOH and LOI, which have contributed to some of the mechanisms of both phenotypic expression of genes and gene mapping in man.

Loss of heterozygosity ( $\mathrm{LOH}$ ) and loss of genomic imprinting (LOI). The term "loss of heterozygosity" has been widely used in the field of human cancer genetics by providing a method for mapping chromosomal areas potentially containing tumor suppressor genes in different types of tumors (Table 20).

Genomic imprinting is also implicated in tumorigenesis (Table 21). An

Table 20. Loss of heterozygosity in tumorigenesis.

\begin{tabular}{ll}
\hline \multicolumn{1}{c}{ Neoplasma } & \multicolumn{1}{c}{$\begin{array}{c}\text { Chromosome site of deletion } \\
\text { (Gene involved) }\end{array}$} \\
\hline Retinoblastoma & $13 \mathrm{q} 14(R B 1)$ \\
Wilms' tumor & $11 \mathrm{p} 13(W T I)$ \\
Neurofibromatosis type 1 & $17 \mathrm{q} 11(N F-1)$ \\
Neurofibromatosis type 2 & $22 \mathrm{q} 12(N F-2)$ \\
Multiple polyposis of the large intestine & $5 \mathrm{q} 21(A P C)$ \\
Hereditary non-adenomatous cancer of the colon & $2 \mathrm{p} 16(M S H 2)$ \\
Breast and ovarian cancer & $17 \mathrm{q} 21(B R C A 1)$ \\
Malignant melanoma & $9 \mathrm{p} 21(C D K N 2)$ \\
Multiple endocrine neoplasia type 2A & $10 \mathrm{q} 11.2(M E N 2 A)$ \\
Pancreatic carcinoma & $18 \mathrm{q} 21(D P C 4)$ \\
Angiomyolipoma & $9 \mathrm{q} 34(T S C 1)$ \\
Cancer of the large intestine & $5 \mathrm{q}(A P C, M C C), 8 \mathrm{p}, 17 \mathrm{p}(p 53)$, \\
& $18 \mathrm{q} 21(D C C), 22$ \\
Small cell carcinoma of the lung & $3 \mathrm{p} 22(S C L C 1), 13 \mathrm{q}(R B I), 17 \mathrm{p}(\mathrm{p} 53)$ \\
Breast cancer & $1 \mathrm{p}, 3 \mathrm{p}, 11 \mathrm{p}, 13 \mathrm{q} 12(B R C A 2), 13 \mathrm{q} 14$ \\
& $(R B I), 17 \mathrm{p}(\mathrm{p} 53), 17 \mathrm{q} 21(B R C A 1)$ \\
Hepatic cell carcinoma & $4 \mathrm{q}, 11 \mathrm{p}, 13 \mathrm{q}, 16 \mathrm{q}, 17$ \\
\hline Compiled by J. Miyoshi (Takai Biotimer Project, ERATO/JST, Ohsaka). [226].
\end{tabular}

Table 21. Loss of imprinting in tumorigenesis.

\begin{tabular}{|c|c|c|}
\hline Gene & Chromosome & Neoplasma \\
\hline$I G F 2$ & $11 \mathrm{p} 15.5$ & $\begin{array}{l}\text { Wilms' tumor, Beckwith-Wiedemann syndrome, glioma, cerebellum } \\
\text { and medulloblastoma, hepatoblastoma, Ewing's sarcoma, ovarian } \\
\text { cancer, breast tumor, cervical carcinoma, bladder carcinoma, lung } \\
\text { cancer, esophageal cancer, leiomyosarcoma, rhabdomyosarcoma }\end{array}$ \\
\hline$H 19$ & $11 \mathrm{p} 15.5$ & $\begin{array}{l}\text { Wilms' tumor, cerebellum and medulloblastoma, testicular germ } \\
\text { cell tumors, breast tumor, lung cancer, esophageal cancer, cervical } \\
\text { carcinoma, bladder carcinoma }\end{array}$ \\
\hline$p 57 K I P 2$ & $11 \mathrm{pl} 5.5$ & $\begin{array}{l}\text { Wilms' tumor, Beckwith-Wiedemann syndrome, soft tissue sarcoma, } \\
\text { lung cancer }\end{array}$ \\
\hline
\end{tabular}

Compiled by J. Miyoshi (Takai Biotimer Project, ERATO/JST, Ohsaka). [226, 258]. 
extreme case involving the whole genome is the hydatidiform mole, an androgenetic placental tumor, in which two entire sets of chromosomes are of paternal origin. The opposite genome constitution is observed in a subset of ovarian teratomas which arise from parthenogenetically activated eggs. The phenotypes of these tumors fit well with the features of androgenetic and parthenogenetic mouse embryos, respectively [90]. It is widely accepted that either or both of the following two events are involved in tumorigenesis, namely: the inactivation of tumor suppressor or growth-repressing genes and the activation of oncogenic or growthpromoting genes [258].

\section{Human gene mapping}

A number of methods have been used in human gene mapping since an autosomal gene was first mapped in 1968 [259]: linkage test using family data, evaluation of the gene-dosage effect, analysis by somatic cell hybridization, karyotype analysis of chromosomal aberrations, determination of homologies of synthetic loci, linkage analysis using RFLP markers, radiation-induced gene segregation, etc. [178]. Among these methods, the linkage analysis has become more powerful since multiple DNA based genetic markers, based upon short tandem repeats, developed for all human chromosomes. In addition, it is noteworthy that advanced methods of localizing a gene on a particular chromosome such as in situ hybridization, fluorescent in situ hybridization, microdissection have recently become available (p. 274).

Two monumental studies of human gene mapping. The elucidation of the molecular basis for progressive muscular dystrophy was the first successful application of the technology of positional cloning to the isolation of dystrophin, the product of an X-linked gene.

The complete dystrophin cDNA, the largest known gene in man located on the short arm of chromosome $\mathrm{X}$, was isolated by Kunkel and his colleagues in 1985. The isolation of the dystrophin gene has provided investigators with a lot of information on mutations which particularly involve the Duchenne and Becker types of muscular dystrophy $[260,261]$.

As compared with such X-linked muscular dystrophy, there remain many difficulties in mapping genes responsible for the diseases in which the gene products causing the diseases have not been isolated. In such diseases a certain amount of luck is required to obtain significant evidence for linkage between a particular gene and some genetic marker. Huntington's disease was such a successful case $[104,262,263]$.

Gussella and his colleagues $(1983,1986)$ studied two large kindreds with many affected members using 12 DNA probes. One probe designated "G8," derived from a recombinant bacteriophage from a human gene library, was noted to detect two invariable and several variable $H$ indIII fragments in human genomic DNA. It turned out that there were several polymorphic sites for this enzyme in

Vol. 42, No. 2, 1997 
relatively close proximity so that the frequency of recombination between them was negligible, that is they were transmitted together as a unit $[262,263]$. The haplotypes were designated A, B, C, and D. In a North-American family the A haplotype was associated with Huntington's disease; in a Venezuelan family it was the C haplotype. Subsequently, a DNA probe designated D4S10 was generated which was estimated to be four recombination units from the disease gene and which was assigned to the terminal band of the short arm of chromosome $4[104$, $262,263]$.

Some improvements in the linkage analysis. In addition to a long-standing method such as the lod score method, affected sibpair method and location score method have developed in the linkage analysis [264], and the calculations in the analysis have not become difficult by using a computer program specifically designed for calculations.

The human genome project. Major projects in the medical biology that remain to be studied before the 21 st century may be the following: high-dimensional functions of the brain, development (ontogeny), aging process, prophylaxis and treatment of cancer, automaticity of the heart, immunity and autoimmunity, etc. The completion of the human genome project will undoubtedly promote the solution of these major projects in the medical biology [265-267].

The human genome project, which started in 1989, has set itself three major scientific goals: creation of genetic maps, development of physical maps, and determination of the complete sequence of human DNA [268].

The goal in the first round of the human genome project may be the identification of the complete set of human genes and the sequencing of the entire human DNA in which the haploid genome consists of approximately $3 \times 10^{9}$ base pairs. In parallel to the human genome, the genome projects of organisms familiar to man will progress: mouse, drosophila, yeast, worms, bacteria, etc. [73, 178, 265-268].

Table 22. Development of the technology for accelerating human gene mapping.

1. Development in laboratory procedure

Positional cloning

Fluorescent in situ hybridization

Microdissection

Cloning of large DNA fragments using YAC or BAC chromosomes

Mapping based on cloning of human-mouse hybrid cells

In vivo experimental systems (transgenic animal, knock-out animal, etc.)

2. Improved efficiency in laboratory procedure

Improvement in the automatic DNA sequencer

Utilization of robots

Development of bioinformatics using computer systems

3. Advance in international exchange of informations Improvement and development of gene library

Maintenance and compilation of data base on DNA fragments

Exchange of informations between investigators through the Internet Systems 
It is estimated that the goal in the first round may be attained much earlier than previously expected due to the combined development of gene manipulation and computer technology as shown in Table 22. Among a number of excellent technologies, in vivo experimental systems such as transgenic animals and knockout animals will be powerful tools particularly in the study of gene action [269271]. The target date for the first round is presumed to be the years 2005-2010 [265-268].

A large proportion of genomic DNA remains for which at present there is no defined function, and due to mechanisms which we still do not comprehend, it preserves its own existence within the genome. However, this part of the DNA sequence will be identified to have significant functions as research progresses [73].

Mitochondrial genome. The DNA sequence of human mitochondrial genome was determined by Anderson and his colleagues in 1981, and thereafter 37 loci were mapped including about 17 kinds of mitochondrial disorders due to point mutations or deletions in mitochondrial DNA $[259,272]$.

The DNA Data Bank of Japan (DDBJ) is outlined in Appendix 3.

\section{An ecogenetic problem in the present and future-man and microbes}

The ecogenetics covers the study of genetically determined differences in susceptibility to the action of physical, chemical, and infectious agents in the environment [273]. Such differences in susceptibility may be either unifactorial or multifactorial in causation.

Among the ecogenetic problems with which man is confronted at present, this

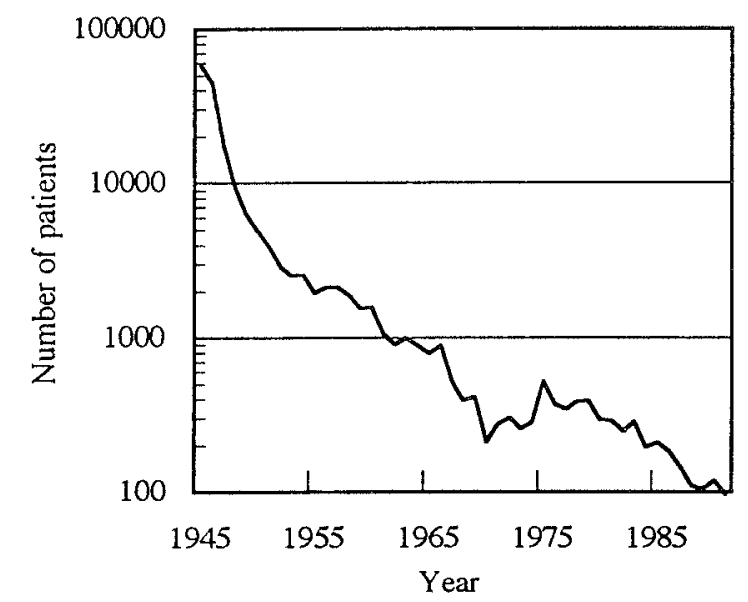

Fig. 5. Yearly change in the number of patients with typhoid fever in Japan.

Reports from the Japan Association of Health \& Welfare Statistics (1980, 1982, 19984, and 1992). [277]. 
section focuses on the interrelations between man and microbes which may be an important and serious issue in the future as well as in the present.

A. Change in infection in the past decades

Man's ability to control the environment has rapidly. and remarkably increased with cultural development in the past hundred years [274]. One such manifestation of this trend is the ascendancy of infectious and contagious diseases.

In the decades following World War II, the campaigns against small pox and polio suggested that people could possibly rid themselves of world epidemics [275]. Antibiotics, vaccines; and sanitation cured infections that used to only be accepted as fate. As a result, neonatal and infantile deaths have been greatly reduced, and the average life span has dramatically increased.

At the time the eradication of small pox was declared in 1980, huge reductions were also seen in typhoid fever, a representative acute infectious disease designated by law in Japan (Fig. 5), and Encephalitis japonica, rabies, and other fatal infectious diseases had all nearly disappeared in Japan.

At this point of time, some human geneticists said that there was dramatic trend toward the control of the infectious and contagious disease entities, and as a result, an increasing proportion of medical attention will be forcibly directed toward those diseases in which the "host factor" or endogenous factor appears to be relatively more important.

Just a few decades later, on the other hand, it was difficult to appreciate such trends. Table 23 gives the infectious diseases showing strong virulence and infectivity which began to appear in the peak polio years, and then more and more erupted [275]. As when any new infection appeared, there still remained doubts as to whether it is new or has just been newly recognized, but they were almost unknown until the years described in the Table 23.

Table 23. A partial list of new diseases and the years of their first appearance or recognition. Isolated cases or localized epidemics of some bad occurred earlier.

\begin{tabular}{ll|ll}
\hline Year & \multicolumn{1}{c|}{ Infectious disease } & Year & \multicolumn{1}{c}{ Infectious disease } \\
\hline 1951 & Korean hemorrhagic fever & 1970 & Human toxoplasmosis \\
1953 & Dengue hemorrhagic fever & 1975 & Lyme disease \\
1953 & Argentine hemorrhagic fever & 1976 & Ebola fever \\
1955 & Chikungunya & 1976 & Legionnaires' disease \\
1956 & Kyasanur Forest disease & 1977 & Adult T-cell leukemia \\
1957 & Human babesiosis & 1977 & Rift Valley fever \\
1959 & O'nyong-nyong fever & 1980 & Toxic shock syndrome \\
1960 & Bolivian hemorrhagic fever & 1981 & AlDS \\
1961 & Oropouche & 1982 & Escherichia coli O157: H7 \\
1965 & LaCrosse encephalitis & 1984 & Brazilian purpuric fever \\
1967 & Marburg disease & 1986 & Human ehrilichiosis \\
1967 & Intestinal capillariasis & 1989 & Venezuelan fever \\
1968 & Pontiac fever & 1989 & Toxic-shock-like syndrome \\
1969 & Lassa fever & 1993 & Hantavirus pulmonary syndrome \\
\hline
\end{tabular}

Karlen 1995 [275]. 
It may be fresh in the memory of most Japanese that a new strain (O157: H7) of the common microbe Escherichia coli prevailed in Sakai City and other parts of Japan in 1996, thus raising worries about the safety of the public supply of food.

In addition to the infectious diseases listed in Table 23, there are also a number of acute and chronic infectious diseases that have returned or again become wide spread after previously having been localized, limited, or controlled.

Man has made strenuous efforts to domesticate wild animals since the ancient times. Such efforts had resulted in an increase in opportunity that microbes are transmitted from animals to man. It is said that the man shares more than 400 kinds of microbes with domesticated and wild animals [275]. However, such a situation in zoonosis appears to change probably due to variations occurring in microbes.

\section{B. Factors leading to disease emergence}

Major factors leading to the emergence of infectious disease may be presumed as follows: an increase in the size of population with a higher density, rapidly increasing discrepancy between the size of population and the availability of the resources to support the population, changes in the environment on the earth with special reference to global warming caused by the burning fossil fuel and massive deforestation, development of scientific technology and industry, changes in human life style and behavior, extension of international communication by travel and trade, progress in medicine, microbial adaptation and change, etc. [275, 276, 278].

Among these factors, this section will focus on the factors of "microbial adaptation and change."

Drugs and medical technology. A wide variety of drugs have been introduced to medical practice by the rapid development of industry of synthetic chemistry over the past few decades. An increasing number of new drugs has led to increasing amounts of iatrogenic disorders. A research area of genetic variations in response to drugs - pharmacogenetics was thus established in the years from 1957 to 1965 as a subdivision of ecogenetics (xenogenetics), which covers the hereditary factors in the response of microbes to drugs as well as those in man [279-281].

Changes in the age structure in the population and the widespread use of immunosuppressants have also led to an increase in immunocompromised hosts. Infections of more than 1,100 kinds of opportunistic microbes have been noted with an increase in drug-resistant microbes at medical institutions $[92,93]$.

The development of medical technology, particularly involving invasive procedures has also resulted in an increased opportunity of infection in parallel to an increase in immunocompromised hosts, and the development of industrial technologies related to building equipment has also made legionellosis common around the world [275].

Vol. 42, No. 2, 1997 
Microbial adaptation and change. Many microbes have shown mutational changes in their genomes that alter their infectivity, virulence, and resistance to environmental changes.

Methicillin-resistant Staphylococcus aureus (MRSA) is a mutant strain which began to prevail all over Japan in the early 1980s. Hiramatsu and his associates (1992) studied the genomic changes in MRSA strain N315. Molecular cloning and analysis of nucleotide sequence of this strain revealed that two open reading frames (orfs) were identified in the $5^{\prime}$-flanking region of the mecA gene. These orfs were thought to encode the putative co-inducer and repressor proteins specific for the regulation of methicillin resistance in MRSA [282].

In addition, it should also be kept in mind that a lot of drugs including antibiotics have also been given to domesticated animal species for food. Such customs also influence the precipitated resistance of microbes to drugs.

The genetically determined vital system in man, particularly involving the immune system, does not appear to have yet been exposed to a sufficient number of arrangements to respond to such changes in microbes.

\section{Concluding remarks}

According to a survey in 1993, progress in the treatment of inborn errors of metabolism was better than it had been, but it was still only a partial success. The advances were attributable to greater success with organ and tissue transplantation, better pharmacotherapy, and better support systems [283]. Restoration of normal homeostasis, the key to successful treatment, remains an elusive challenge and is a logical major focus for research in human genetics [283].

Since the first recombinant molecules were generated in 1972, great improvements have been made in the accuracy of risk estimation of hereditary diseases [73]. With the progress of the human genome project, people will soon be able to make more well-informed decisions in the risk estimation of hereditary diseases, and before long such common diseases as cancer, diabetes, Alzheimer's disease,

Table 24. Factors altering human reproduction.

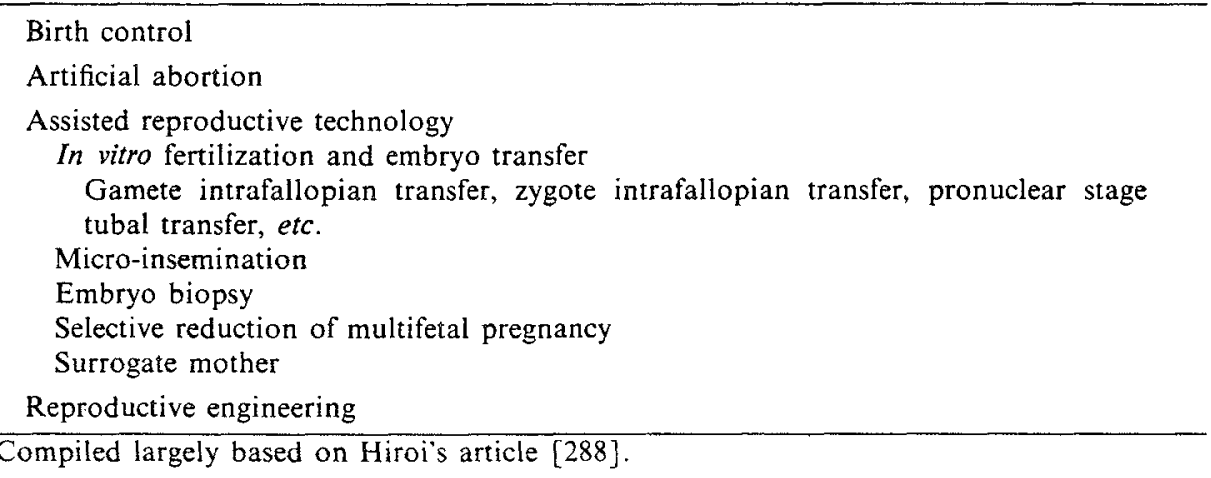


etc., will likely also be subject to genetic counseling.

Under these circumstances, the rights of people to remain ignorant of such risk for a given disease as well as the rights to know such risks should be ensured. More specifically, close attentions should be paid to the protection of such informations on the genetic constitutions of each individuals to preserve their privacy, and to obtain a nation-wide understanding and agreement on the application of DNA technology to the practice in medicine including gene diagnosis and therapy. A number of reports on the guidelines of genetic counseling, which will be required in the era of DNA technology, have recently been published [284-287].

Finally, the author would like to arouse the interest of the members of the Society to the recent trends in the technology pertinent to human reproduction as shown in Table 24. These technologies will sooner or later raise many new issues regarding ethical problems as well as various factors related to altering the genetic constitutions of human populations.

\section{Appendix data}

APPENDIX 1. Pioneers of human genetics in Japan.

\begin{tabular}{|c|c|c|c|c|c|}
\hline Name & $\begin{array}{l}\text { Year of birth } \\
\text { and death }\end{array}$ & City & Name & $\begin{array}{l}\text { Year of birth } \\
\text { and death }\end{array}$ & City \\
\hline Hisomu Nagai & $1876-1957$ & Tokyo & Minoru Itoh & $1894-1982$ & Sendai \\
\hline Taku Komai & $1886-1972$ & Kyoto & Riichi Kawakami & $1895-1982$ & Tokyo \\
\hline Seizo Katsunuma & $1886-1963$ & Nagoya & Kunizo Fukuda & $1896-1988$ & Tokyo \\
\hline Tsunekichi Ueda & $1887-1966$ & Nara & Yushi Uchimura & $1897-1980$ & Tokyo \\
\hline Shyungo Ohsato & $1888-1974$ & Sendai & Shufu Yoshimasu & $1899-1974$ & Tokyo \\
\hline Yoshio Koya & $1890-1974$ & Tokyo & Toratoshi Taniguchi & $1902-1991$ & Tokyo \\
\hline Tanemoto Furuhata & $1891-1975$ & Tokyo & Sajiro Makino & $1906-1986$ & Sapporo \\
\hline Tando Misao & $1893-1994$ & Fukuoka & & & \\
\hline
\end{tabular}

APPENDIX 2. List of studies and recipients of the Japan Society of Human Genetics Award (1960-1996).

\begin{tabular}{lll}
\hline Year & Name of recipient & \multicolumn{1}{c}{ Title of studies awarded } \\
\hline 1960 & Shigeo Takahara & Studies on acatalasemia \\
1961 & Ei Matsunaga & Selection due to mother-fetus ABO incompatibility \\
1962 & Ujihiro Murakami & Developmental mechanisms of congenital anomalies \\
1963 & Hisatoshi Mitsuda & Clinical genetic studies in psychiatry \\
1964 & Susumu Shibata \& Akira & Studies on hereditary nigremia (Hb M Iwate) \\
& Tamura & Pharmacogenetic studies of INH metabolism \\
1965 & Shigeichi Sunahara & A study of isolated populations \\
1966 & Toshiyuki Yanase & Chromosome studies in human subjects \\
1967 & Sajiro Makino & Biochemical genetic studies of blood group substances \\
1968 & Shoei Iseki & Studies on twins \\
1969 & Eiji Inouye & Theoretical studies of human population genetics \\
1970 & Motoo Kimura & Studies on cis AB blood group \\
1972 & Hideo Yamaguchi & Genetic studies on the stature \\
1973 & Toshiyuki Furusho & Genetic studies of inbreeding \\
1976 & Katumi Tanaka &
\end{tabular}

Vol. 42, No. 2, 1997 


\begin{tabular}{|c|c|c|}
\hline Year & Name of recipient & Title of studies awarded \\
\hline 1977 & Masatoshi Nei & $\begin{array}{l}\text { Theoretical studies on molecular population genetics and } \\
\text { evolution in man }\end{array}$ \\
\hline 1978 & Yoshio Okada & Studies of somatic cell genetics utilizing cell hybridization \\
\hline 1979 & Shiro Miwa & $\begin{array}{l}\text { Erythrocyte enzyme system and its clinical and } \\
\text { biochemical studies }\end{array}$ \\
\hline 1980 & Susumu Ohno & Studies on sex determination in mammals including man \\
\hline 1981 & Akira Yoshida & Biochemical genetic studies on human enzyme variation \\
\hline 1983 & Keiya Tada & Studies on inborn errors of metabolism \\
\hline 1985 & Tadashi Kajii & $\begin{array}{l}\text { Studies on androgenesis of hydatidiform mole, and } \\
\text { related studies }\end{array}$ \\
\hline 1986 & Teruo Kitagawa & $\begin{array}{l}\text { An animal model of human acid sphingomyelinase } \\
\text { deficiency (Niemann-Pick's disease) and the study of its } \\
\text { enzyme replacement }\end{array}$ \\
\hline 1988 & Masao S. Sasaki & Cytogenetic studies on hereditary factors for oncogenesis \\
\hline 1989 & Takehiko Sasazuki & $\begin{array}{l}\text { Genetic control of immune response and disease } \\
\text { susceptibility }\end{array}$ \\
\hline 1992 & Kiyoji Tanaka & $\begin{array}{l}\text { Molecular analysis of xeroderma pigmentosum group A } \\
\text { gene }\end{array}$ \\
\hline 1993 & Kazuya Mikamo & Cytogenetic studies of reproduction \\
\hline 1994 & Ichiro Matsuda & $\begin{array}{l}\text { Molecular aspects of inherited metabolic disorders of } \\
\text { amino acids }\end{array}$ \\
\hline 1995 & Yusuke Nakamura & Roles of DNA markers in medicine \\
\hline 1996 & Tadao Orii & $\begin{array}{l}\text { Molecular basis of } \beta \text {-ketothiolase deficiency, } \\
\text { mucopolysaccharidosis and Zellweger syndrome }\end{array}$ \\
\hline
\end{tabular}

\section{APPENDIX 3. DNA Data Bank of Japan (DDBJ)}

The DDBJ DNA data bank was started in 1986 with the endorsement of the Ministry of Education, Science, Sports and Culture of Japan, and representative molecular biologists in Japan.

From the beginning it was intended that the DDBJ should be operated as one of the International DNA Databases including the Bioinformatics Institute (EBI) at European Molecular Biology Laboratories (EMBL) in Europe and the National Center for Biotechnology Information at the National Institute of Health in the USA (GenBank/KCBI/NIH) as the two other members. Consequently, the DDBJ has been collaborating with these two data banks mainly by daily exchanges of collected data at each bank through international networks, and by holding two annual meetings, the International DNA Data Bank Advisors Meeting and the International Data Bank Collaborators Meeting.

The DDBJ is the sole DNA data bank in Japan, which is officially certified to collect DNA sequences from investigators and which can issue accession numbers to the data submitters

The DDBJ collects data mainly from Japanese investigators, but of course accept data and issue accession numbers to investigators in any other countries. It has been noted that since the DDBJ exchanges data with EBI and GenBank/NCBI on daily basis, the three data banks share virtually the same data at any moment.

The DDBJ also provides investigators worldwide with various on-line data retrieval services such as FASTA, BLAST, CLUSTALW, MALIGN and Key word searches. Please refer to:

http;//www.ddbj.nig.ac.jp for more information.

[Reference] Takeno Y \& Gojobori T (1996) DNA Data Bank of Japan in the age of information biology. Nucl Acids Res. 25: 14-17. 
Acknowledgments I express my gratitudes to Professor K. Kondo, President of the 41 st Meeting of the Japan Society of Human Genetics, and Professor S. Miwa, the previous chairman of the Board of Directors of the Society, who gave me the opportunity of this memorial lecture. A number of my colleagues and friends helped me by taking care of my poor health after a surgical operation, collecting sources of information, reading the manuscript, and making fair copies. These people are the following:

Drs. Y. Niho, Y. Kaji, H. Nakashima, S. Nagafuchi, S. Kobayashi, T. Ohtsuka, Y. Tanaka, and Miss N. Asano (First Department of Medicine, Kyushu University), Drs. K. Sugimachi and K. Komori (Second Department of Surgery), Dr. J. Miyoshi (Takai Biotimer Project, ERATO, Ohsaka), Drs. T. Imamura and T. Gojobori (National Institute of Genetics), Drs. Y. Yanagi, Y. Fukumaki, H. Sasaki, T. Sasazuki, T. Suzuki, S. Kashiwagi, and J. Hayashi (Kyushu University), Drs. Y. Takihara (Ohsaka University), H. Hamaguchi (Tsukuba University), Y. Nishimura (Kumamoto University), M. Yamaguchi and A. Ohta (Saga Medical College), Y. Yasukochi, A. Kimura, and S. Kitajima (Tokyo Medical and Dental University), Dr. A. Nakajima (Juntendo University), Y. Yoshida (Sendai), and M. Kawamura (Keio University).

\section{REFERENCES}

The references on the cases of mutants, biochemical variants, and abnormalities have been eliminated from the following list because the number of references have been too large. However, the author would be happy to provide any of the references not listed here upon request.

[1] The Japan Society of Human Genetics (1956) The first general assembly of the Japan Society of Human Genetics. Jpn J Human Genet 1: 54-60 (in Jpn)

[2] Tanaka K (1981) Recollections of the days when the Japan Society of Human Genetics was founded. Heredity (Iden) 35: 72-80 (in Jpn)

[ 3 ] Matsunaga E (1992) History of human genetics and eugenics in Japan, with a comment by W.J. Schull. In: History and Development of Human Genetics: Progress in Different Countries (Ed: Dronomaraju KR). World Publ Co, New Jersey, etc.

[4] Furuhata T, Ichida K, \& Kishi T (1925) Biochemical structure of human blood cells and its heredity. Jpn Sci Assoc Rep (Gakujutsu Kyoukai Houkoku) 1: 314-325 (in Jpn)

[5] Komai T \& Fukuoka G (1936) Frequency of multiple births among Japanese and related people. Am J Phys Anthrop 21: 433-447

[6] Imai Y \& Moriwaki D (1936) A probable case of cytoplasmic inheritance in man: A critique of Leber's disease. J Genet 33: 163-167

[7] Stern C (1949) The Principles of Human Genetics. 1st ed, Freeman Co, San Francisco

[ 8 ] Crow JF (1950) Genetics Notes. 1st ed, Burgess Publ Co, Minneapolis, Minnesota

[9] Neel JV \& Schull WJ (1954) Human Heredity. 1st ed, Univ Chicago Press, Chicago

[10] Tanaka K (Katumi) (1960) Fundamental Human Genetics. 1st ed, Shokabo, Tokyo (in Jpn)

[11] Publication Committee of Mendel Centennial Anniversary in Japan (Ed) (1967) Upon the Steps from Mendel. Shokabo, Tokyo (in Jpn)

[12] Neel JV \& Schull WJ (1956) The Effects of Exposure to the Atomic Bombs on Pregnancy Termination in Hiroshima and Nagasaki. Natl Res Concil, Washington, DC

[13] Kimura M \& Ohta T (1971) Theoretical Aspects of Population Genetics. Princeton Univ Press, Princeton, New Jersey

[14] Vogel F \& Motsulsky AG (1986) Human Genetics-Problems and Approaches. 2nd ed, Springer-Verlag, Berlin, etc.

[15] Fisher RA (1918) The correlation between relatives on the supposition of Mendelian inheritance. Trans R Soc (Edinburgh) 52: 399-433

[16] Fisher RA (1970) Statistical Methods for Research Workers. 14th ed, Oliver \& Boyd, Edinburgh

[17] Haldane JBS (1932) The Causes of Evolution. Harper \& Row, New York

Vol. 42, No. 2, 1997 
[18] Haldane JBS (1932) A method for investigating recessive characters in man. J Genet 25 : $251-255$

[19] Haldane JBS (1936) Search for incomplete sex-linkage in man. Ann Eug 7: 28-57

[20] Wright S (1931) Evolution in Mendelian populations. Genetics 16: 97-159

[21] Wright S (1934) The results of crosses between inbred strains of guinea pigs differing in number of digits. Genetics 19: 537-551

[22] Morton NE (1955) Sequential tests for the detection of linkage. Am J Hum Genet 7: $277-$ 318

[23] Flemming W (1897) Über die Chromosomenzahl beim Menschen. Anat Arz 14: 171

[24] Tjio JH \& Levan A (1956) The chromosome numbers of man. Hereditas 42: 1-6

[25] Lejeune J, Gautier M, \& Turpin R (1959) Etude des chromosomes somatiques de neuf enfants mongoliens. C R Acad Sci (Paris) 248: 1721-1722

[26] Matsunaga E (1993) Developments of human genetics: Recollections and current perspectives. Heredity (Iden) Special Issue, No 5: 7-13 (in Jpn)

[27] Caspersson T, Zech L, Johansson C, et al. (1970) identification of human chromosomes by DNA-binding fluorescent agents. Chromosoma 30: 215-227

[28] Paris Conference (1971) Standardization in human cytogenetics. 1972. Birth Defects: Original Article Series 8 (no. 7). The Natl Found-March of Dimes, New York, 46 pp

[29] ISCN (1985) An International System for Human Cytogenetic Nomenclature. Pub in Collab with Cytogenet Cell Genet, Kagel, etc.

[30] Carr DH (1967) Chromosome anomalies as a cause of spontaneous abortion. Am J Obstet Gynecol 97: 283-293

[31] Kuroki Y (1995) Loss of zygote due to chromosomal aberrations. In: Human Genetics -Principles and Practice (Ed: Yanase T). Kanehara Shuppan, Tokyo, 317-321 (in Jpn)

[32] Garrod AE (1902) The incidence of alcaptonuria: a study in chemical individuality. Lancet ii: $1616-1620$

[33] Beadle GM \& Tatum EL (1941) Genetic control of biochemical reactions in neurospora. Proc Natl Acad Sci USA 27: 499-506

[34] Fölling A (1934) Über Ausscheidung von Phenylbrenztraubensäure in den Harn als Stoffwechselanomalie in Verbindung mit Imbezilität. Hoppe-Seyeler's Z Physiol Chem 227: $169-176$

[35] Jervis GA (1953) Phenylpyruvic oligophrenia: Deficiency of phenylalanine oxidizing system. Proc Soc Exp Biol Med 82: 514-515

[36] Gibson QH (1948) The reduction of methaemoglobin in red blood cells and studies on the cause of idiopathic methaemoglobinemia. Biochem $J$ 42: 13-23

[37] Takahara S \& Miyamoto H (1949) Clinical and experimental studies on progressive gangrenous odontitis probably due to deficiency of catalase in blood. Oto-Rhino-Laryngol (Jibi-Inkoka) 21: 53-56 (in Jpn)

[38] Cori GT \& Cori CF (1952) Glucose-6-phosphatase of the liver in glycogen storage disease. J Biol Chem 199: 661-667

[39] Pauling L, Itano HA, Singer SJ, et al. (1949) Sickle cell anemia: A molecular disease. Science 110: $543-548$

[40] Ingram VM (1956) A specific chemical difference between the globins of normal human and sickle cell anemia haemoglobin. Nature 178: 792-794

[41] Sutter J \& Tabah L (1954) The break-up of isolates. Eug Quart 3: 148-154

[42] Nei M \& Imaizumi Y (1963) Random mating and frequency of consanguineous marriages. Ann Rep Natl Radiol Sci: 48

[43] Yanase T (1966) A study of isolated populations. Jpn J Human Genet 11: 125-161 (in Jpn)

[44] Yanase $T$ (1992) Time trends in the break-up of isolates. In: Isolation, Migration and Health (Eds: Roberts DF et al.). Cambridge Univ Press, New York, etc.: 23-28

[45] Neel JV, Yanase T, \& Schull WJ (1965) Consanguinity studies in Japan. World Population Conference, 1965. Vol II: Fertility, Family Planning, Mortality. UN, New York: 486493 
[46] Yanase T (1962) The use of the Japanese family register for genetic studies. Proc of UN/ WHO Seminar on the Use of Vital and Health Statistics for Genetic and Radiation Studies: $119-133$

[47] Schull WJ \& Neel JV (1962) The child health survey: a genetic study in Japan. Proc of UN/WHO Seminar on the Use of Vital and Health Statistics for Genetic and Radiation Studies: $171-193$

[48] Komai T (1964) A report from the Subcommittee of Consanguinity Studies. The Communication Committee on Genetic Researches, Japan Sci Council, pp 21 (in Jpn)

[49] Komai T \& Tanaka T (Eds) (1972) Genetic studies on inbreeding in some Japanese populations. Jpn J Humam Genet 17: 87-366

[50] Neel JV \& Schull WJ (1962) The effect of inbreeding on mortality and morbidity in two Japanese cities. Proc Natl Acad Sci USA 48: 573-582

[51] Schull WJ \& Neel JV (1965) The Effect of Inbreeding on Japanese Children. Harper \& Row, New York, pp 419

[52] Yamaguchi $M$, Yanase T, Nagano H, et al. (1970) Effects of inbreeding on mortality in Fukuoka population. Am J Hum Genet 22: 145-159

[53] Schull WJ \& Neel JV (1972) The effect of parental consanguinity and inbreeding in Hirado, Japan. V. Summary and interpretation. Am J Hum Genet 24: 425-453

[54] Tanaka K (1972) Effects of inbreeding on mortality in Shizuoka. Jpn J Human Genet 17: 319-331

[55] Muller HJ (1950) Our load of mutation. Am J Hum Genet 2: 111-176

[56] Morton NE, Crow JF, \& Muller HJ (1956) An estimate of the mutational damage in man from data on consanguneous marriages. Proc Natl Acad Sci USA 42: 855-863

[57] Morton NE (1960) The mutational load due to detrimental genes in man. Am J Hum Genet 12: $348-364$

[58] Crow JF (1958) Some possibilities for measuring selection intensities in man. Hum Biol 30: $1-13$

[59] Crow JF \& Morton NE (1960) The genetic load due to mother-child incompatibility. Am Naturalist 94: 413-419

[60] Crow JF (1963) The concept of genetic load; A reply. Am J Hum Genet 15: 310-315

[61] Kimura M (1961) Some calculations on the mutational load. Jpn J Genet 36 (Suppl): 179190

[62] Levene $H$ (1963) Inbred genetic loads and the determination of population structure. Proc Natl Acad Sci USA 50: 587-591

[63] Li CC (1963) The way the load ratio works. Am J Hum Genet 15: 316-321

[64] Sanghvi LD (1963) The concept of genetic load; A critique. Am J Hum Genet 15: 298-309

[65] Shull WJ, Yanase T, \& Nemoto H (1962) Kuroshima: The impact of religion on an island's genetic heritage. Hum Biol 34: 271-298

[66] Neel JV (1970) Lessons from a "primitive" people. Science 170: 815-822

[67] Yanase T (1964) A note on the patterns of migration in isolated populations. Jpn J Human Genet 9: 136-152

[68] Dausset J (1958) Iso-leuco-anticorps. Acta Haemat (Basel) 20: 156-166

[69] Nowell PC \& Hungerford DA (1960) A minute chromosome in human chronic granulocytic leukemia. Science 132: 1497

[70] Okada Y (1962) Analysis of giant polynuclear cell formation caused by HVJ virus from Ehrlich's ascites tumor cells. Exp Cell Res 26: 98-107

[71] Avery OT, Macleod CM, \& Carty M (1944) Studies on the chemical nature of the substance including transformation of pneumococcal types. J Exp Med 79: 137-156

[72] Hershey $\mathrm{AD} \&$ Chase $M$ (1952) Independent functions of viral protein and nucleic acid in growth of bacteriophage. J Gen Physiol 36: 39-56

[73] Emery AEH \& Malcolm S (1995) An Introduction to Recombinant DNA in Medicine. 2nd ed, John Wiley \& Sons, Chichester, etc.

[74] Sutton HE (1975) An Introduction to Human Genetics. Holt, Rinehart \& Winston, New York, etc.

Vol. 42, No. 2, 1997 
[75] Langer-Safer PR, Levine M, \& Ward DC (1982) Immunological method for mapping genes on Drosophila polytene chromosomes. Proc Natl Acad Sci USA 79: 4381-4385

[76] Pinkel D, Straume T, \& Gray JW (1986) Cytogenetic analysis using quantitative, high sensitivity, fluorescence hybridization. Proc Natl Acad Sci USA 83: 2934-2938

[77] Pinkel D, Landegent J, Collins C, et al. (1988) Fluorescence in situ hybridization with human chromosome-specific libraries: Detection of trisomy 21 and translocation of chromosome 4. Proc Natl Acad Sci USA 85: 9138-9142

[78] Ludecke HJ, Senger G, Claussen U, et al. (1989) Cloning defined regions of the human genome by microdissection of banded chromosomes and enzymatic amplication. Nature 338: $348-350$

[79] Senger G, Ludecke HJ, Horsthemke B, et al. (1990) Microdissection of banded human chromosomes. Hum Genet 84: 507-511

[80] Lyon MF (1961) Gene action in the X-chromosome of the mouse (Mus musculus L). Nature 190: 372-373

[81] Shapiro LJ, Mohandas T, Weiss R, et al. (1979) Non-inactivation of an X-chromosome locus in man. Science 204: 1224-1226

[82] Mohandas T, Sparkes RS, Hellkuhl B, et al. (1980) Expression of an X-linked gene from an inactive human $X$-chromosome in mouse-human hybrid cells: Further evidence for the non-activation of the steroid sulfatase locus in man. Proc Natl Acad Sci USA 77: 67596763

[83] Brown CJ, Ballabio A, Rupert JL, et al. (1991) A gene from the region of the human X inactivation center is expressed exclusively from the inactive chromosome. Nature 349: 38 44

[84] Sutherland GR \& Hecht F (Eds) (1985) Fragile Sites of Human Chromosomes. Oxford Univ Press, Oxford

[85] Chandley AE \& Hagerman RJ (1987) Fragile X syndrome. J Pediatr 110: 821-831

[86] Arinami T (1995) Fragile sites and fragile X syndrome. In: Human Genetics-Principles and Practice (Ed: Yanase T). Kanehara Shuppan, Tokyo, 233-237 (in Jpn)

[87] Emanuel BS (1988) Molecular cytogenetics: Toward dissection of the contiguous gene syndrome. Am J Hum Genet 43: 575-578

[88] Kuroki Y \& Sasaki H (1995) Molecular cytogenetics. In: Human Genetics-Principles and Practice (Ed: Yanase T). Kanehara Shuppan, Tokyo, 221-231 (in Jpn)

[89] Solter D (1988) Differential imprinting and expression of maternal and paternal genomes. Ann Rev Genet 22: 127-146

[90] Nakao M \& Sasaki H (1996) Genomic imprinting: significance in development and diseases and the molecular mechanisms. J Biochem 120: 467-473

[91] Eisenstein BI (1990) The polymerase chain reaction: a new method of using molecular genetics for medical diagnosis. $\mathrm{N}$ Engl J Med 322: 364-366

[92] Mori T (Ed) (1996) Gene Diagnosis and Therapy 1996-The Second Conference of Gene Diagnosis and Therapy. Igaku-Shoin, Tokyo (in Jpn)

[93] Miyaji H (1996) Gene diagnosis of infectious diseases. In: Gene Diagnosis and Therapy (Ed: Mori T). Igaku-Shoin, Tokyo, 27-28 (in Jpn)

[94] Saitou N \& Nei M (1987) The neighbor-joining methods: A new method for reconstructing phylogenetic trees. Mol Biol Evol 4: 406-425

[95] Gojobori T, Moriyama EN, Ina Y, et al. (1990) Evolutionary origin of human and simian immunodeficiency viruses. Proc Natl Acad Sci USA 77: 7328-7332

[96] The Japanese Society of Internal Medicine (1990, 1993, 1996) Programs of the 87th, 90th, and 93rd Annual Meetings of the Japanese Society of Internal Medicine (Special Issues), pp 210,280, 272 (in Jpn)

[97] Braunitzer G, Hilschmann N, Rudloff V, et al. (1961) The haemoglobin particles. Chemical and genetic aspects of their structure. Nature 190: 480

[98] Kendrew JC, Dickerson RE, Strandberg BE, et al. (1960) Structure of myoglobin-a three-dimensional Fouries synthesis at $2 \AA$ resolution. Nature 185: 422-427 
[99] Perutz MF (1976) Structure and mechanism of haemoglobin. Br Med Bull 32: 195-208

[100] Pelham HRB \& Jackson RJ (1976) An efficient mRNA-dependent translation system from reticulocyte lysates. Eur J Biochem 67: 247-256

[101] Proudfoot NJ, Shander MHM, Manley JL, et al. (1980) Structure and in vitro transcription of human globin genes. Science 209: 1329-1336

[102] Lawn RM, Fritsch EF, Parker RC, et al. (1978) The isolation and characterization of linked $\delta$ - and $\beta$-globin genes from a cloned library of human DNA. Cell 15: 1157-1174

[103] Weatherall DJ \& Clegg JB (1979) Recent development in the molecular genetics of human hemoglobin. Cell 16: 467-479

[104] Weatherall DJ (1991) The New Genetics and Clinical Practice. 3rd ed, Oxford Univ Press, Oxford, etc.

[105] Efstratiadis A, Posakony JW, Maniatis T, et al. (1980) The structure and evolution of the human $\beta$-globin gene family. Cell 21: $653-668$

[106] Lehmann H \& Carrel RW (1969) Variations in the structure of human haemoglobin. Br Med Bull 25: 14-23

[107] Sharp PA (1994) Split genes and RNA splicing. Cell 77: 805-815

[108] Jeffreys AJ \& Flavell RA (1977) The rabbit of $\beta$-globin gene contains a large insert in the coding sequence. Cell 112: 1097-1108

[109] Jeffreys AJ (1977) DNA sequence variants in the ${ }^{\mathrm{C}} \gamma,{ }^{\mathrm{A}} \gamma, \delta$ - and $\beta$-globin genes of man. Cell 18: $1-10$

[110] Goodbourne SEY, Higgs DR, Clegg JB, et al. (1983) Molecular basis of length polymorphism in the human $\xi$-globin gene complex. Proc Natl Acad Sci USA 80: 5022-5026

[111] Orkin SH (1990) Globin gene regulation and switching: Circa 1990. Cell 63: 665-672

[112] Kan KW, Golbus MS, \& Dozy AM (1976) Prenatal diagnosis of $\alpha$-thalassemia. Clinical application of molecular hybridizations. N Engl J Med 295: 1165-1167

[113] Perutz MF \& Lahmann H (1968) Molecular pathology of human hemoglobin. Nature 219: 902-909

[114] Imamura T, Fukumaki Y, \& Nakashima $H$ (1995) Mutations at the molecular level and molecular pathology. In: Human Genetics-Principles and Practice (Ed: Yanase T). Kanehara Shuppan, Tokyo, 283-306 (in Jpn)

[115] Cheng, T-C (1981) Post-transcriptional modification of globin RNA. In: Human Hemoglobins and Hemoglobinopathies; A Review to 1981. Univ Texas Med Branch, Galveston, $87-100$

[116] Treisman R, Orkin SH, \& Maniatis T (1983) Specific transcription and RNA splicing defects in five cloned $\beta$-thalassemia genes. Nature 302: 591-596

[117] Kazazian HH Jr (1990) The thalassemia syndromes: Molecular basis and prenatal diagnosis in 1990. Seminars Hematol 27: 209-228

[118] Fukumaki Y \& Fucharoen S (1991) Generation and spread of globin gene mutation in population: $\beta$-thalassemia in Asian countries. In: New Aspects of the Genetics of Molecular Biology (Eds: Kimura M \& Takahata N). Springer-Verlag, Berlin, 153-176

[119] Thein SL (1992) Dominant $\beta$ thalassemia: Molecular basis and pathophysiology. $\mathrm{Br} J$ Haematol 80: 273-277

[120] Cao A (1994) William Allan address. Am J Hum Genet 54: 397-402

[121] Clegg JB, Weatherall DJ, \& Milner PF (1971) Hemoglobin Constant Spring-a chain termination mutant? Nature (Lond) 234: $337-340$

[122] Gerald PS \& Diamond LK (1958) A new hereditary hemoglobinopathy (the Lepore trait) and its interaction with thalassemia trait. Blood 13: 835-844

[123] Lehmann H \& Charlesworth D (1970) Observation on haemoglobin P (Congo type). Biochem J 119: 43P

[124] Ohta Y, Yamaoka K, Sumida I, et al. (1971) Hemoglobin Miyada, a $\beta-\delta$ fusion peptide (anti-Lepore) type discovered in a Japanese family. Nature New Biol 234: $218-220$

[125] Hockwald RS, Arnold J, Clayman CB, et al. (1952) Status of primaquine: IV. Toxicity of primaquine in negroes. JAMA 149: 1560-1570 
[126] Dern RJ, Weistein IM, LeRoy GV, et al. (1954) The hemolytic effect of primaquine. I. The localization of the drug-induced hemolytic defect in primaquine-sensitive individuals. $J$ Lab Clin Med 43: 303-309

[127] Beutler E, Dern RJ, Flanagan CL, et al. (1955) The hemolytic effect of primaquine. VII. Biochemical studies of drug-sensitive erythrocytes. J Lab Clin Med 45: 286-295

[128] Carson PE, Flanagan CL, Ikes CE, et al. (1956) Enzymatic deficiency in primaquinesensitive erythrocytes. Science 124: 484-485

[129] Luzzatto L \& Metha A (1995) G6PD deficiency. In: The Metabolic Basis of Inherited Disease (Eds: Scriver CR ei al.). 7th ed, McGraw-Hill, New York, 3367-3398

[130] Boyer SH, Porter IH, \& Weilbacher RG (1962) Electrophoretic herterogeneity of G6PD and its relationship to enzyme deficiency in man. Proc Natl Acad Sci USA 48: 1868-1876

[131] Kirkman HN, Schettini F, \& Picard BM (1964) Mediterranean variant of G6PD. J Lab Clin Med 63: 726-735

[132] Yoshida A (1967) A single amino acid substitution (asparagine to aspartic acid) between normal $(\mathrm{B}+)$ and the common negro variant $(\mathrm{A}+)$ of human G6PD. Proc Natl Acad Sci USA 57: $835-840$

[133] Persico MG, Viglietto G, Martini G, et al. (1986) Isolation of human G6PD cDNA clones: Primary structure of the protein and unusual 5 '-non-coding region. Nucleic Acids Res 14: $2511-2522$

[134] Takizawa T, Huang I-Y, Ikuta T, et al. (1986) Human G6PD: Primary structure and cDNA cloning. Proc Natl Acad Sci USA 83: 4157-4161

[135] Rowland P, Basak AK, Gover S, et al. (1994) The three-dimensional structure of G6PD from Leuconostoc mesenteroides refined at $2.0 \AA$ resolution. Structure 2: 1073-1087

[136] Naylor CE, Rowland P, Basak AK, et al. (1996) G6PD mutations causing enzyme deficiency in a model of the tertiary structure of the human enzyme. Blood 87: 2974-2982

[137] Betke K, Beutler.E, Brewer GJ, et al. (1967) Standardization of procedures for the study of G6PD. Report of a WHO Scientific Group. WHO Tech Rep Ser 366

[138] Takizawa $T$, Yoneyama Y, Miwa S, et al. (1987) A single nucleotide base transition is the basis of the common human G6PD variant A (+). Genomics 1: 228-231

[139] Beutler E, Vulliamy T, \& Luzzatto L (1996) Hematologically important mutations: G6PD. Blood Cells Mol Dis 22: 49-56

[140] Miwa S \& Fujii H (1996) Molecular basis of erythroenzymopathies associated with hereditary hemolytic anemia: Tabulation of mutant enzymes. Am J Hematol 51: 122-132

[141] Smith GP (1974) Unequal crossover and the evolution of multigene families. Cold Spring Harbor Symp Quant Biol 38: 507-513

[142] Ohta T (1982) Allelic and non-allelic homology of a super gene family. Proc Natl Acad Sci USA 79: $3251-3254$

[143] Ohta $T$ (1983) On the evolution of multigene families. Theor Pop Biol 23: 216-240

[144] Ohta T (1991) Multigene families and the evolution of complexity. J Mol Evol 33: 34-41

[145] Sanghvi LD (1953) Comparison of genetical and morphological methods for a study of biological differences. Am J Phys Anthrop 11: 385-404

[146] Cavalli-Sforza LL \& Edwards AWF (1967) Phylogenetic analysis: Models and estimation procedures. Am J Hurn Genet 19: 233-257

[147] Harris $H$, Hopkinson A, \& Robson EB (1974) The incidence of rare alleles determining electrophoretic variants: Data on 43 enzyme loci in man. Ann Hum Genet 37: 237-253

[148] Nei M (1972) Genetic distance between populations. Am Naturalist 106: 283-292

[149] Nei M \& Roychoudhury AK (1974) Genetic variation within and between the three major races of man, Caucasoid, Negroid, and Mongoloid. Am J Hum Genet 26: 421-443

[150] Kimura M (1968) Evolutionary rate at the molecular level. Nature 217: 624-626

[151] King JL \& Jukes TH (1969) Non-Darwinian evolution. Science 164: 788-798

[152] Kimura M \& Ohta T (1971) Protein polymorphism as a phase of molecular evolution. Nature 229: 467-469

[153] Nei M, Fuerst PA, \& Chakraborty R (1976) Testing the neutral mutation hypothesis by 
distribution of single locus heterozygosity. Nature 262: 491-493

[154] Ohta T (1976) Role of very slightly deleterious mutations in molecular evolution and polymorphism. Theor Pop Biol 10: 254-275

[155] Miyata T, Yasunaga T, \& Nishida T (1980) Nucleotide sequence divergence and functional constraint mRNA evolution. Proc Natl Acad Sci USA 77: 7328-7332

[156] Li W-H, Gojobori T, \& Nei M (1981) Pseudogenes as a paradigm of neutral evolution. Nature 292: 237-239

[157] Miyata T \& Yasunaga T (1981) Rapidly evolving mouse alpha-globin related pseudogene and its evolutionary history. Proc Natl Acad Sci USA 78: 450-453

[158] Gojobori T, Moriyama EN, \& Kimura M (1990) Molecular clock of viral evolution and the neutral theory. Proc Natl Acad Sci USA 87: 10015-10018

[159] Takahata N, Satta T, \& Klein J (1992) Polymorphism and balancing selection at major histocompatibility complex loci. Genetics 130: $925-938$

[160] Endo, T, Ikeo K, \& Gojobori T (1996) Large-scale search for genes on which positive selection may operate. Mol Biol Evol 13: $685-690$

[161] Neel JV \& Schull WJ (Eds) (1991) The Children of Atomic Bomb Survivors. A Genetic Study. Nat Acad Press, Washington DC

[162] Satoh C (1995) Biochemical studies on the offspring of atomic bomb survivors. In: Effects of A-Bomb Radiations on the Human Body (Ed: Hiroshima Internat Counc for Med Care of the Rad-Exp). Harwood Acad Publ, US, Bunkodo Co, Tokyo, 358-365

[163] Neel JV, Satoh C, Goriki K, et al. (1986) The rate with which spontaneous mutation alters the electrophoretic mobility of polypeptides. Proc Natl Acad Sci USA 83: 389-393

[164] Satoh C \& Neel JV (1988) Biochemical mutations in the children of atomic bomb survivors. In: Gann Monograph on Cancer Research. No. 35. Genetics of Human Tumors in Japan (Eds: Takebe H \& Utsunomiya J). Jpn Sci Soc, Tokyo, 191-208

[165] Neel JV, Satoh C, Goriki K, et al. (1988) Search for mutations altering protein charge and/or function in children of aromic bomb survivors: Final report. Am $J$ Hum Genet 42: 663-676

[166] Kodaira M, Satoh C, Hiyama K, et al. (1995) Lack of effects of atomic bomb radiation on genetic instability of tandem-repetitive elements in human germ cells. Am J Hum Genet 57: $1275-1283$

[167] Satoh C \& Kodaira M (1996) Effects of radiation on children. Nature 383: 226

[168] Satoh C, Takahashi N, Asakawa J, et al. (1996) Genetic analysis of children of atomic bomb survivors. Environ Health Perspect 104 (Suppl 3): 511-519

[169] Asakawa J, Kuick R, Neel JV, et al. (1995) Quantitative and qualitative genetic variation in two-dimensional DNA gels of human lymphocytoid cell lines. Electrophoresis 16: 241252

[170] Tarui S, Ohkubo G, Ikura Y, et al. (1965) Phosphofructokinase deficiency in skeletal muscle. A new type of glycogenesis. Biochem Biophys Res Commun 19: 517-523

[171] Yamasaki T, Nakajima H, Kono N, et al. (1991) Structure of the entire human muscle phosphofructokinase-encoding gene: a two promoter system. Gene 104: 27-282

[172] Tada K, Narisawa K, Yoshida T, et al (1969) Hyperglycinemia: A defect in glycine cleavage reaction. Tohoku J Exp Med 98: 289-296

[173] Tada K (1994) Pathophysiology of hyperglycinemia. Molec Med 31: 260-273 (in Jpn)

[174] Fukuyama Y, Kawazura M, \& Haruna H (1960) A peculiar form of congenital muscular dystrophy. Report of fifteen cases. Paediatria Univ Tokyo 4: 5-8

[175] Toda T, Segawa M, Nomura Y, et al. (1993) Localization of a gene for Fukuyama type congenital muscular dystrophy to chromosome 9q31-33. Nature Genet 5: 283-286

[176] Kuroki Y, Suzuki Y, Chyo H, et al. (1981) A new malformation syndrome of long palpebral fissures, large ears, depressed nasal tip, and skeletal anomalies associated with postnatal dwarfism and mental retardation. J Pediatr 99: 570-573

[177] Niikawa N, Matsuura N, Fukushima Y, et al. (1981) Kabuki make-up syndrome. A syndrome of mental retardation, unusual facies, large and protruding ears, and postnatal 
growth deficiency. J Pediatr 99: 565-569

[178] Passarge E (1995) Color Atlas of Genetics. Georg Thieme Verlag, Stuttgart, etc.

[179] Ross JD \& Rosenbaum E (1964) Paroxysmal nocturnal hemoglobinuria presenting as aplastic anemia in a child. Am J Med 37: 130-139

[180] Inoue $\mathrm{N}$, Kinoshita $\mathrm{T}$, Orii $\mathrm{T}$, et al. (1992) Cloning of a human gene, PIG-F, a component of glycosylphophatidylinositol anchor biosynthesis, by a novel expression cloning strategy. J Biol Chem (Commun) 268: 6882-6885

[181] Takeda J \& Kinoshita T (1995) GPI-anchor biosynthesis. Elsevier Trends J Rev TIBS 20: $367-370$

[182] Koide R, Ikeuchi $T$, Onodera $O$, et al. (1994) Unstable expansion of CAG repeat in hereditary dentatorubral-pallidoluysian atrophy (DRPLA). Nature Genet 6: 9-13

[183] Nagafuchi S, Yanagisawa H, Sato K, et al. (1994) Dentatorubral and pallidoluysian atrophy expansion of an unstable CAG trinucleotide on chromosome 12p. Nature Genet 6: $14-18$

[184] Yazawa I, Nukina N, Hashida $H$, el al. (1995) Abnormal gene product'identified in hereditary dentatorubral-pallidoluysian atrophy (DRPLA) brain. Nature Genet 10: $99-$ 103

[185] Ikeuchi T, Igarashi S, Takayama Y, et al (1996) Non-Mendelian transmission in dentatorubral pallidoluysian atrophy and Machado-Joseph disease: The mutant allele is preferentially transmitted in male meiosis. Am J Hum Genet 58: 730-733

[186] Tsuji S (1996) Unstable expansion of triplet repeats as a new disease mechanism for neurodegenerative diseases. Jpn J Human Genet 41: 279-290

[187] Shaw MW, Falls HF, \& Neel JV (1960) Congenital aniridia. Am J Hum Genet 12: 389

[188] Fuhrmann W (1963) Das Syndrom der erblichen Nephropathie mit Innenohrschwerhörigkeit (Alport-Syndrom). Dtsch Med Wochenschr 88: 525-532

[189] Munier F, Spence MA, Pescica G, et al. (1992) Paternal selection favoring mutant alleles of the retinoblastoma susceptibility gene. Hum Genet 89: 508-5!2

[190] Evans K, Fryer A, Inglehearn C, et al. (1994) Genetic linkage of cone-rod retinal dystrophy to chromosome $19 q$ and evidence for segregation distortion. Nature Genet 6: 210-213

[191] Jarvik GP, Patton MA, Homfray T, et al. (1994) Non-Mendelian transmission on a human developmental disorder: split hand/split foot. Am J Hum Genet 55: 710-713

[192] Hurst GDD, Hurst LD, \& Barrett JA (1995) Meiotic drive and myotonic dystrophy. Nature Genet 10: 132-133

[193] Singer M \& Berg P (1991) Genomic Rearrangements in "Genes and Development," Univ Sci Books, Mill Valley, CA, 713-822

[194] Hozumi N \& Tonegawa S (1976) Evidence for somatic rearrangement of immunoglobulin genes coding for variable and constant regions. Proc Natl Acad Sci USA 73: 3628-3632

[195] Tonegawa S (1983) Somatic generation of antibody diversity. Nature 302: 575-581

[196] Honjo T \& Kataoka T (1978) Organization of immunoglobulin heavy chain and allelic deletion model. Proc Natl Acad Sci USA 75: 2140-2144

[197] Kataoka T, Kawakami T, Takahashi N, et al (1980) Rearrangement of immunoglobulin $\gamma 1$-chain gene and mechanism for heavy chain class switch. Proc Natl Acad Sci USA 77: 919-923

[198] Yanagi Y, Yoshikai Y, Leggett $K$, et al. (1984) A human $T$ cell-specific cDNA clone encodes a protein having extensive homology to immunoglobulin chains. Nature 308: 145149

[199] Hedrick SM, Cohen DI, Nielsen EA, et al. (1984) Isolation of cDNA clones encoding T cell-specific membrane-associated proteins. Nature 308: $149-153$

[200] Matsuoka M, Nagawa F, Okazaki K, et al. (1991) Detection of somatic DNA recombination in the transgenic mouse brain. Science 254: $81-86$

[201] Anderson SJ, Levin SD, \& Perlmutter RM (1993) Protein tyrosine kinase p56 ${ }^{\text {Ick }}$ controls allelic exclusion of $T$-cell receptor $\beta$-chain genes. Nature $365: 552-554$ 
[202] Mather K (1949) Biometrical Genetics. Dover, New York

[203] Grüneberg H (1952) Genetical studies of the skeleton of the mouse. IV. Quasicontinuous variations. J Genet 51: 95-114

[204] Edwards JH (1960) The simulation of Mendelism. Acta Genet (Basel) 10: 63-70

[205] Carter CO (1961) The inheritance of congenital pyloric stenosis. Br Med Bull 32: 21-26

[206] Falconer DS (1965) The inheritance of liability to certain diseases, estimated from the incidence among relatives. Ann Hum Genet 29: 51-76

[207] Sasazuki T, McDevitt HO, \& Grumet FC (1977) The association between genes in the major histocompatibility complex and disease susceptibility. Ann Rev Med 28: 425-452

[208] Inouye E (1961) Similarity and dissimilarity of schizophrenia in twins. In: Proc III World Congr Psychiat. Vol 1, Univ Toronto Press, Toronto: 524-530

[209] Inouye E (1968) Schizophrenia. In: Clinical Genetics (Eds: Inouye E \& Yanase T). Asakura Shoten, Tokyo: 387-408 (in Jpn)

[210] Heston LL (1966) Psychiatric disorders in foster home reared children of schizophrenic mother. Br J Psychiatr 112: 819-825

[211] Rosenthal D, Wender PH, Kety SS, et al. (1971) The adopted-away offspring of schizophrenics. Am J Psychiatr 128: 307-311

[212] Sherrington R, Brynjolfesson J, Pertusson H, et al. (1988) Localization of a susceptibility locus for schizophrenia on chromosome 5. Nature 336: 164-167

[213] Corder EH, Saunders AM, Strittmatter WJ, et al. (1993) Gene dosage of apolipoprotein E type 4 allele and the risk of Alzheimer's disease in late onset families. Science 261: 921 923.

[214] Connor JM \& Ferguson-Smith MA (1988) Essential Medical Genetics. 2nd ed, Blackwell Sci, Oxford

[215] Nanjo K, Sanke T, Miyano M, et al. (1996) Diabetes due to secretion of a structurally abnormal insulin (Insulin Wakayama). Clinical and functional characteristics of [LeuA3] insulin. J Clin Invest 77: 514-519

[216] Kadowaki T, Bevins CL, Cama A, et al. (1988) Two mutant alleles of the insulin receptor gene in a patient with extreme insulin resistance. Science 240: 787-790

[217] Yoshimasa Y, Seino S, Whittaker J, et al. (1988) Insulin-resistant diabetes due to a point mutation that prevents insulin proreceptor processing. Science 240: 784-787

[218] Kadowaki H, Tobe K, Mori Y, et al. (1993) Mitochondrial gene mutation and insulindeficient type of diabetes mellitus. Lancet 341: 893-894

[219] Kadowaki T (1996) Mitochondrial gene mutation and diabetes. Jpn J Intern Med (Nippon Naikagaku Zasshi) 85: 574-577 (in Jpn)

[220] Oka Y, Katagiri H, Yazaki Y, et al. (1993) Mitochondrial gene mutation in islet-cellantibody-positive patients who were initially non-insulin-dependent diabetes. Lancet $\mathbf{3 4 2}$ : $527-528$

[221] Yamagata K, Oda N, Kaisaki PJ, et al. (1996) Mutations in the hepatocyte nuclear factor- $1 \alpha$ gene in maturity-onset diabetes of the young (MODY3). Nature 384: 455-457

[222] Vionnet N, Stoffel LM, Takeda J, et al. (1992) Nonsense mutation in the glucokinase gene causes early-onset non-insulin-dependent diabetes mellitus. Nature 356: 721-722

[223] Sakura H, Eto K, Kadowaki H, et al. (1992) Structure of the human glucokinase gene and identification of a missense mutation in a Japanese patient with early-onset non-insulindependent diabetes mellitus. J Clin Endocrinol Metab 75: 1571-1573

[224] Katagiri H, Asano T, Yamanouchi T, et al. (1993) Glucokinase-defective NIDDM. Lancet 341: 961-962

[225] Yamagata K, Furuta H, Oda N, et al. (1996) Mutation in the hepatocyte nuclear factor-4a gene in maturity-onset diabetes of the young (MODY 1). Nature 384: 458-460

[226] Miyoshi J \& Motomura S (1995) Genetics of neoplasmas. In: Human Genetics-Principles and Practice (Ed: Yanase T). Kanehara Shuppan, Tokyo, 381-394 (in Jpn)

[227] Fujinami A \& Inemoto K (1910) An experiment on transplantation of chicken tumor. Kyoto Med J (Kyoto Igaku-Zasshi) 7: 31-32 (in Jpn) 
[228] Rous P (1911) Transmission of a malignant new growth by means of a cell-free filtrate. J Am Med Assoc 56: 198

[229] Lynch HT (1976) Cancer Genetics. Thomas, Springfield

[230] Weinberg RA (Ed) (1989) Oncogene and the Molecular Origins of Cancer. Cold Spring Harbor Laboratory Press, Cold Spring Harbor

[231] Rowley JD (1973) A new consistent chromosomal abnormality in chronic myelogenous leukemia identified by quinacrine fluorescence and Giemsa staining. Nature 234: 290-293

[232] Knudson AG Jr (1971) Mutation and cancer: Statistical study of retinoblastoma. Proc Natl Acad Sci USA 68: 820-823

[233] Cavenee WK, Dryja TP, Phillips WF, et al. (1983) Expression of recessive alleles by chromosomal mechanisms in retinoblastoma. Nature 305: 779-784

[234] Takatsuki K (Ed) (1994) Adult T-Cell Leukimia. Oxford Univ Press, Oxford

[235] Poiesz BJ, Ruscetti FW, Gazdar AF, et al. (1980) Detection and isolation of type C retrovirus particles from fresh and cultured lymphocytes of a patient with cutaneous T-cell lymphoma. Proc Natl Acad Sci USA 77: 7415-7419

[236] Miyoshi I, Kubonishi I, Sumida M, et al. (1979) Characteristics of a leukemic T-cell line derived from adult T-cell leukemia. Jpn J Clin Oncol 9: 485-494

[237] Hinuma Y, Nagata K, Hanaoka M, et al. (1981) Adult T-cell leukemia: antigen in an adult $\mathrm{T}$-cell leukemia cell line and detection of antibodies to the antigen in human sera. Proc Natl Acad Sci USA 78: 6476-6480

[238] Yoshida M, Seiki M, Hattori S, et al. (1984) Genome structure of human T-cell leukemia virus and its involvement in the development of adult T-cell leukemia/lymphoma. In: Human T-Cell Leukemia/Lymphoma Virus (Eds: Gallo R et al.). Cold Spring Harbor Lab Press, Cold Spring Harbor, 141-148

[239] Shih C \& Weinberg RA (1982) Isolation of a transforming sequence from a human bladder carcinoma cell line. Cell 29: 161-169

[240] Goldfarb M, Shimizu K, Perucho M, et al. (1982) Isolation and preliminary characterization of a human transforming gene from T24 bladder carcinoma cells. Nature 296: 404-409

[241] Parada LF, Tabin CJ, Shih C, et al. (1982) Human EJ bladder carcinoma oncogene is homologue of Harvey sarcoma virus ras gene. Nature 297: 474-478

[242] Santos E, Tronick SR, Aaronsen SA, et al. (1982) T24 human bladder carcinoma oncogene is an activated form of the normal human homologue of BALB- and HarveyMSV transforming genes. Nature 298: 343-347

[243] Reddy EP, Reynolds RK, Santos E, et al. (1982) A point mutation is responsible for the acquisition of transforming properties by the T24 human bladder carcinoma onogene. Nature 300: $149-152$

[244] Stehelin D, Varmus HE, Bishop JM, et al. (1976) DNA related to the transforming gene(s) of avian sarcoma viruses is present in normal avian DNA. Nature 260: 170-173

[245] Takeya T \& Hanafusa H (1983) Structure and sequence of the cellular gene homologous to the RSV src gene and the mechanism for generating the transforming virus. Cell 32: $881-890$

[246] Friend SH, Bernards R, Rogelj S, et al. (1986) A human DNA segment with properties of the gene that predisposes to retinoblastoma and osteosarcoma. Nature 323: 643-646

[247] Lane DP \& Crawford L (1979) T antigen is bound to a host protein in SV40 transformed cells. Nature 278: 26I-263

[248] Linzer DIH \& Levine AJ (1979) Characterization of a 54k dalton cellular SV40 tumor antigen present in SV40 transformed cells and uninfected embryonal carcinoma cells. Cell 17: $43-52$

[249] Joslyn G, Carison M, Thliveries A, et al. (1991) Identification of deletion mutations and three new genes at the familial polyposis locus. Cell 66: 601-613

[250] Nishisho I, Nakamura Y, Miyoshi Y, et al. (1991) Mutations of chromosome 5q21 genes in FAP and colorectal cancer patients. Science 253: 665-669

[251] Miki Y, Swensen J, Shattuck-Eidens D, et al. (1994) A strong candidate for the breast and 
ovarian cancer susceptibility gene $B R C A 1$. Science 266: 66-71

[252] Doolittle RF, Hunkapiller MW, Hood LE, et al. (1983) Simian sarcoma virus oncogene $\mathrm{V}$-sis is derived from the gene encoding a platelet-derived growth factor. Science 221: 275 277

[253] Waterfield MD, Scrace T, Whittle N, et al. (1983) Platelet-derived growth factor is structurally related to the putative transforming protein p28sis of Simian sarcoma virus. Nature 304: 35-39

[254] Downward J, Yarden Y, Mayers E, et al. (1984) Close similarity of epidermal growth factor receptor and v-erbB oncogene protein sequences. Nature 307: 521-527

[255] Collet MS \& Erikson RL (1978) Protein kinase activity associated with the avian sarcoma virus src gene product. Proc Natl Acad Sci USA 75: 2021-2024

[256] Tsujimoto Y, Yunis J, Onoratoshowe L, et al. (1984) Molecular cloning of the chromosomal breakpoint of B-cell lymphomas and leukemias with the $t(11 ; 14)$ chromosome translocation. Science 224: 1403-1406

[257] Itoh N, Yonehara S, Ishii A, et al. (1991) The polypeptide encoded by the cDNA for human cell surface antigen Fas can mediate apotosis. Cell 66: 233-243

[258] Feinberg AP (1993) Genomic imprinting and gene activation in cancer. Nature Genet 4: $110-113$

[259] McKusick VA (1994) Mendelian Inheritance in Man. Catalogs of Autosomal Dominant, Autosomal Recessive and X-Linked Phenotypes. 11th ed, Johns Hopkins Univ Press, Baltimore

[260] Kunkel LM, Monaco AP, Middlesworth W, et al. (1985) Specific cloning of DNA fragments absent from the DNA of a male patient with an $\mathrm{X}$ chromosome deletion. Proc Natl Acad Sci USA 82: 4778-4782

[261] Koenig M, Monaco AP, \& Kunkel LM (1988) The complete sequence of dystrophin predicts rod-shaped cytoskeletal protein. Cell 52: 219-228

[262] Gusella JF, Wexler NS, Coneally PM, et al. (1983) A polymorphic DNA marker genetically linked to Huntington's disease. Nature 306: 234-238

[263] Gusella JF, Gilliam TC, Tanzi RE, et al. (1986) Molecular genetics of Huntington's disease. Cold Spring Harbor Symp Quant Biol LI: 359-364

[264] Yasuda N (1995) Linkage and linkage analyses. In: Human Genetics-Principles and Practice (Ed: Yanase T). Kanehara Shuppan, Tokyo, 139-150 (in Jpn)

[265] The Japan Foundation for Aging and Health (1995) A Prospective View of Studies on Aging and Health, pp 19 (in Jpn)

[266] Dulbecco $R$ (1986) A turning point in cancer research: sequencing the human genome. Science 231: 1055-1056

[267] Watson JD (1996) The human genome project: past, present, and future. Science 248: 4449

[268] Jordan E \& Collins FS (1996) A march of genetic maps. Nature 380: 111-112

[269] Palmiter RD \& Brinster RL (1985) Transgenic mice. Cell 41: 343-345

[270] Mansour SL, Thomas KR, \& Capecchi MR (1988) Disruption of proto-oncogene int-2 in mouse embryo-derived stem cells: a general strategy for targeting mutations to non-selectable genes. Nature 336: 348

[271] Capecchi MR (1989) Altering the genome by homologous recombination. Science 240: 1288-1292

[272] Anderson S, Bankier AT, Barrel BG, et al. (1981) Science and organization of the human mitochondrial genome. Nature 290: 457-465

[273] Brewer GJ (1971) Annotation: Human ecology, an expanding role for the human geneticists. Am J Hum Genet 23: 92-94

[274] Neel JV (1959) Medical genetics today. Clin Med Res (Rinsho to Kenkyuh) 36: 419-427 (in $\mathrm{Jpn}$ )

[275] Karlen A (1995) Man and Microbes-Disease and Plaques in History and Modern Times. Quantum Res Assoc, Inc, New York, etc. 
[276] Cockburn A (1983) The Evolution and Eradication of Infectious Diseases. Westport CT, Greenwood

[277] The Japan Health \& Welfare Statistics Association (1980, 1982, 1984, 1992) Indications of Public Welfare and Movements (Special issues) (in Jpn)

[278] Matsunaga E (1975) Demographic trends, family planning and their genetic implications. Tokyo J Med Sci 83: 330-343 (in Jpn)

[279] Motulsky AG (1957) Drug reactions, enzymes and biochemical genetics. JAMA 165: 835837

[280] Vogel F (1959) Moderne Probleme der Humangenetik. Ergeb Inn Med Kinderheilk 12: 52125

[281] Kalow W (1962) Pharmacogenetics: Heredidity and Response to Drugs. WB Saunders Co, Philadelphia

[282] Hiramatsu K, Asada K, Suzuki E, et al. (1992) Molecular cloning and nucleotide sequence determination of the regulator region of mecA gene in methicillin-resistant Staphylococcus aureus (MRSA). Fed Eur Biochem Soc 298: 133-136

[283] Treacy E, Childs B, \& Scriver CR (1995) Response to treatment in hereditary metabolic disease: 1993 survey and 10-year comparison. Am J Hum Genet 56: 359-367

[284] Takahashi K (Ed) (1975) A Guide Book of Gene Diagnosis and Genetic Counseling in Muscular Dystrophies. An investigation sponsored by the Ministry of Health and Welfare (in Jpn)

[285] Handa Y (Ed) (1982) Report on the Committee of Networks of Genetic Counseling in Japan. Jpn J Hum Genet 27: 357-365 (in Jpn)

[286] The Research Group of Handicapped Individuals (Ed: Sakamoto S) (1982) A Guide Book of Genetic Counseling (The Ministry of Health and Welfare), pp 305

[287] Takada F (1995) A proposal from a clinical genetics practician. In: 1995 Research Report from the Study Section on the Issues Related with Human Genome, Medical Service and Clinical Genetics: Today and Future (Ed: Takaku F). The Assoc Scholars on Bioethics (in Ipn)

[288] Hiroi M (1996) Elucidation of the mechanism of fertilization and clinical application of assisted technology. Acta Obstet Gynaecol Jpn 48: 578-590 (in Jpn) 